\title{
Antibacterial activity of graphene-based materials
}

\author{
Authors: Sabine Szunerits* and Rabah Boukherroub \\ Institute of Electronics, Microelectronics and Nanotechnology (IEMN), UMR 8520 CNRS, \\ Lille1 University, Avenue Poincaré - CS60069, 59652 Villeneuve d'Ascq, France. \\ E-mail: sabine.szunerits@ univ-lille1.fr; rabah.boukherroub@univ-lille1.fr; Tel: +33 3625317 \\ 25 Tel: +33362531724
}

First published: 30/08/2016

DOI: $10.1039 / \mathrm{C} 6 \mathrm{~TB} 01647 \mathrm{~B}$

\begin{abstract}
Complications related to infectious diseases have significantly decreased due to the availability and use of a wide variety of antibiotics and antimicrobial agents. However, excessive use of antibiotics and antimicrobial agents over years has increased the number of drug resistant pathogens. Microbial multidrug resistance poses serious risks and consequently research attention has refocused on finding alternatives for antimicrobial treatment. Among the various approaches, the use of engineered nanostructures is currently the most promising strategy to overcome microbial drug resistance by improving the remedial efficiency due to their high surface-to-volume ratio and their intrinsic or chemically incorporated antibacterial activity. Graphene, a two-dimensional ultra-thin nanomaterial, possesses excellent biocompatibility, putting it in the forefront for different applications in biosensing, drug delivery, biomedical device development, diagnostics and therapeutics. Graphene-based nanostructures also hold great promise for combating microbial infections. Yet, several questions remain unanswered such as the mechanism of action with the microbial entities, the importance of size and chemical composition in the inhibition of bacterial proliferation and adhesion, cytotoxicity, and other issues when considering future clinical implementation. This review summarizes the current efforts in the formulation of graphene-based nanocomposites with antimicrobial and antibiofilm activities as new tools to tackle the current challenges in fighting against bacterial targets. Furthermore, the review describes the features of graphene-bacterial interactions, with the hope to shed light on the range of possible mode of actions, serving the goal to develop a better understanding of the antibacterial capabilities of graphene-based nanostructures.
\end{abstract}

\section{Introduction}

1

DOI: 10.1039/C6TB01647B - Journal: Journal of Materials Chemistry B: Materials for biology and medicine - Post-print 
Infectious diseases caused by pathogenic microorganisms such as viruses, bacteria and fungi are still one of the world's most challenging global health issues. While morbidity and mortality from infections decreased considerably from the late 1940s onwards due to the commercialization and use of penicillin, issues related to the emergence of many microorganisms that have become resistant to antibiotics have made the search for the treatment of infectious diseases again of high importance. For example, some of the Gram-positive (e.g. Staphylococcus aureus) and Gram-negative (Escherichia coli, Pseudomonas aeruginosa) bacteria are the common multi-drug resistant (MDR) pathogens and important causes of various often hospital-acquired infections. According to published data in 2011, 25000 patients die annually in the EU as a result of infections caused by antibiotic-resistant bacteria, with twothirds of these deaths due to Gram-negative pathogens. The report entitled "Review on Antimicrobial Resistance" published in December 2014 by J. O-Neill estimates a death quote attributable to antimicrobial resistance (AMR) of 10 million in $2050 .{ }^{1}$ The costs incurred by drug resistant infections amount to an estimated $€ 1.5$ billion annually, due to the increase in healthcare expenditure costs. The situation is all the more serious as antimicrobials have become an essential tool for modern medicine and many surgical operations could not be performed without them. The demand for developing new antimicrobial drugs and therapies for combating bacterial infections has thus become crucial.

Next to the conventional treatments of pathogenic bacteria with antibiotics, other antimicrobial agents such as topical antiseptics, ${ }^{2}$ iodine-containing solutions, ${ }^{3}$ or silver ion containing preparations ${ }^{4}$ can be used. While these approaches have the advantage of surpassing any bacterial resistance mechanism, they are not harmless and generally do not target only bacteria but also normal cells. Absorption of antiseptics such as iodine compounds can cause many adverse effects, such as psychological disorders to skin reactions or acidosis, but also metabolic disorders such as hyperthyroidism. This made iodine not recommended for the treatment of infected wounds. Silver preparations such as silver nitrate or silver sulfadiazine are also used as antimicrobial agents. Taking again the example of wound infections, such compounds are not capable of penetrating deep inside and are ineffective in the treatment of deeply infected wounds and burns. ${ }^{5}$

This and other infection related problems have motivated researchers to concentrate on the development of novel, inexpensive and efficient antimicrobial treatment strategies for fighting pathogenic infections. These strategies are becoming even more important over the years, as, despite extensive efforts in research and enormous investment of resources, the speed of antibiotic development has not kept up with the development of resistance.

The application of materials science and nanotechnology to medicine has shown impressive potential in tackling different aspects of microbial infections. ${ }^{6-11}$ Many nanomaterials have been demonstrated to possess inherent antimicrobial properties that are rarely expressed in their bulk form, with the best known example being silver nanoparticles (Ag NPs). Fig. 1 illustrates some examples of the use of different nanostructures for treatment of infections, for sensing or as inhibitors of biofilm formation.

DOI: 10.1039/C6TB01647B - Journal: Journal of Materials Chemistry B: Materials for biology and medicine - Post-print 


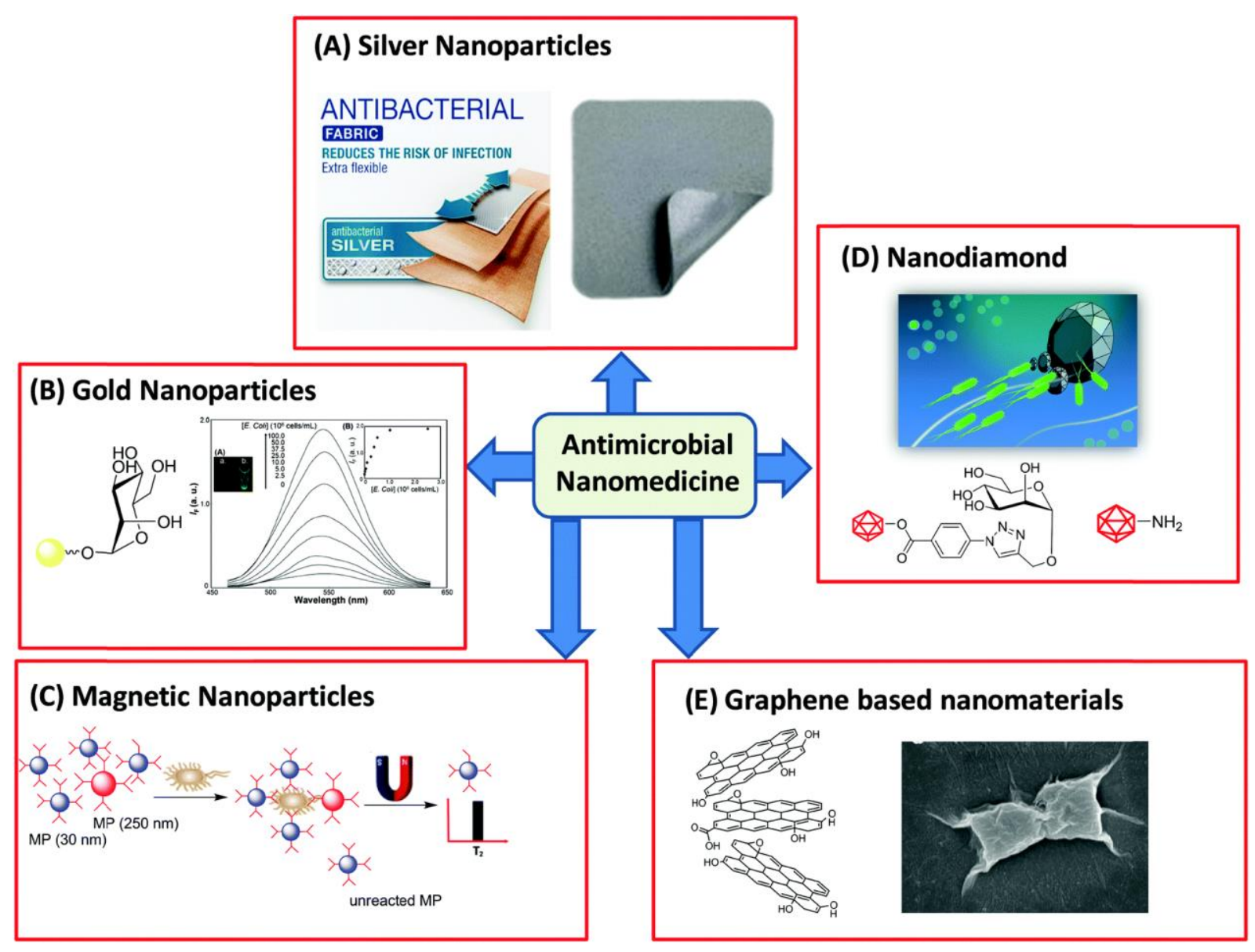

Fig. 1

Different nanoparticles for the detection and ablation of pathogens: (A) the bactericidal action of silver NPs has found its use in wound dressings, patches and antiseptic sprays; (B) use of fluorescent mannose-modified gold nanoparticles (Man-Au NPs) for the detection of E. coli; fluorescence spectra of Man-Au NPs $(25 \mathrm{nM})$ used as probes for the detection of E. coli ((2.50 $\left.\times 10^{6}\right)-\left(1.00 \times 10^{8}\right)$ cells per $\left.\mathrm{mL}\right)$. (Inset A) Visualization of Man-Au NPs $(25 \mathrm{nM})$ in the (a) absence and (b) presence of E. coli $\left(2.50 \times 10^{8}\right.$ cells per $\left.\mathrm{mL}\right)$ upon excitation $(365 \mathrm{~nm})$ under a hand-held UV lamp. (Inset B) Plot of fluorescence intensity $(545 \mathrm{~nm})$ versus E. coli concentration (reprint with permission from ref. 19); (C) schematic illustration of magnetic separation of pathogens and selective detection of $\mathrm{S}$. enterica $\left(10^{5} \mathrm{cfu}\right.$ per $\left.\mathrm{mL}\right)$ (reprint with permission from ref. 12); (D) sugar and amine-modified diamond particles for the inhibition of biofilm formation or as bactericidal probes; $\frac{14-16}{1 E}$ graphene oxide and its bactericidal action on E. coli as shown by the SEM image after incubation with GO $\left(40 \mu \mathrm{g} \mathrm{mL}^{-1}\right)$ for $2 \mathrm{~h}$ (reprint with permission from ref. 13).

Silver nanoparticles (Ag NPs) are probably the oldest nanomaterials used as antibacterial agents. Ag NPs are nowadays present in dressings for surgical wounds, in coating for medical devices as well as in lotions and gels to prevent bacterial and fungal contaminations (Fig. 1A). The mechanism of action of Ag NPs is well studied and is based on the attack of the respiratory chain and cell division that finally leads to cell death, with the concomitant release of silver cations $\left(\mathrm{Ag}^{+}\right)$which enhances the bactericidal activity. While the antibacterial character of $\mathrm{Ag}$ 3

DOI: 10.1039/C6TB01647B - Journal: Journal of Materials Chemistry B: Materials for biology and medicine - Post-print 
NPs appears appealing, practical applications of Ag NPs are often hampered by their aggregation and subsequent loss of antibacterial activity. ${ }^{17}$ In addition, concerns about the cytotoxicity of Ag NPs towards human cells have been voiced. ${ }^{18}$ The use of gold nanoparticles (Au NPs) has received sustained attention over the past few years for pathogen identification ${ }^{19-}$ ${ }^{21}$ and treatment. Hung et al. reported a universal, simple, and convenient method for the preparation of water-soluble, luminescent, mannose modified Au NPs and demonstrated their application for E. coli detection through multivalent cooperative interactions between the mannose modified particles and glycoproteins of the bacterial membrane (Fig. 1B). ${ }^{19}$ Indeed, early detection of foodborne pathogenic bacteria is critical for preventing disease outbreaks and preserving public health. An alternative platform for the simple isolation and detection of $\mathrm{E}$. coli using a magnetic bead (MB)-based sensor that combines magnetic separation (MS) and magnetic relaxation switch (MRS) for one-step detection of bacteria with high sensitivity and reproducibility has been reported recently (Fig. 1C). ${ }^{12}$ Glycan-modified nanodiamonds (glycoNDs) have lately been added to the list of antibacterial agents (Fig. 1C). ${ }^{14-16,22}$ In contrast to metal and metal oxide NPs, NDs are highly stable in corrosive media, which limits their decomposition or transformation to materials with potential toxicity and decreased activity. The antibacterial activity of NDs is strongly guided by their surface composition and charge. While carboxylated and hydroxylated NDs do not exhibit antibacterial activity, aminated ND (ND$\mathrm{NH}_{2}$ ) particles showed bactericidal activity for $\mathrm{S}$. aureus, but not for E. coli. ${ }^{16} \mathrm{Next}$ to the bactericidal effect of the different ND structures, their potential for interfering with the formation of microbial biofilm has been investigated. ${ }^{14,15}$ Mannose-modified NDs were found to be extremely efficient in interfering with biofilm formation of uropathogenic E. coli. ${ }^{14-16}$

Carbon, due to its valency, is able to form several allotropes, resulting in a broad range of structures with different shapes and properties: graphite with bonded carbon atoms in a hexagonal lattice and layered two-dimension sheets, graphene, consisting of a single sheet of graphite, or fullerenes where the carbon atoms are bonded in a hexagonal lattice forming threedimensional cylindrical hollow structures that can be spheres $\left(\mathrm{C}_{60}\right)$, ellipsoids $\left(\mathrm{C}_{70}, \mathrm{C}_{84}\right)$ or tubular (carbon nanotubes, CNTs). In the case of graphene, it is only the pristine form that contains complete $\mathrm{sp}^{2}$ hybridization as a single layer of atoms with no defects (Fig. 2). However, in the literature graphene may also refer to a few layered materials held together by van der Waals forces with a high density of defects such as graphene oxide (GO) and reduced graphene oxide (rGO) (Fig. 2). What makes graphene however of preferential use over other carbonbased materials, such as fullerenes or CNTs ${ }^{23}$ is the fact that in contrast to CNTs, which are grown from carbon-containing gases in the presence of catalytic nanoparticles, depending on the method of formation, graphene and its derivatives can be free of any metallic impurities. As only $50 \mathrm{ppm}$ residual metallic impurities induce substantial cytotoxicity within biological samples, ${ }^{24}$ effective proliferation of human and mammalian cells is limited. The apparent low mammalian cell cytotoxicity of graphene-based materials ${ }^{25-28}$ encouraged investigations of their bactericidal properties as well as their use in inhibiting bacterial attachment.

DOI: $10.1039 /$ C6TB01647B - Journal: Journal of Materials Chemistry B: Materials for biology and medicine - Post-print 


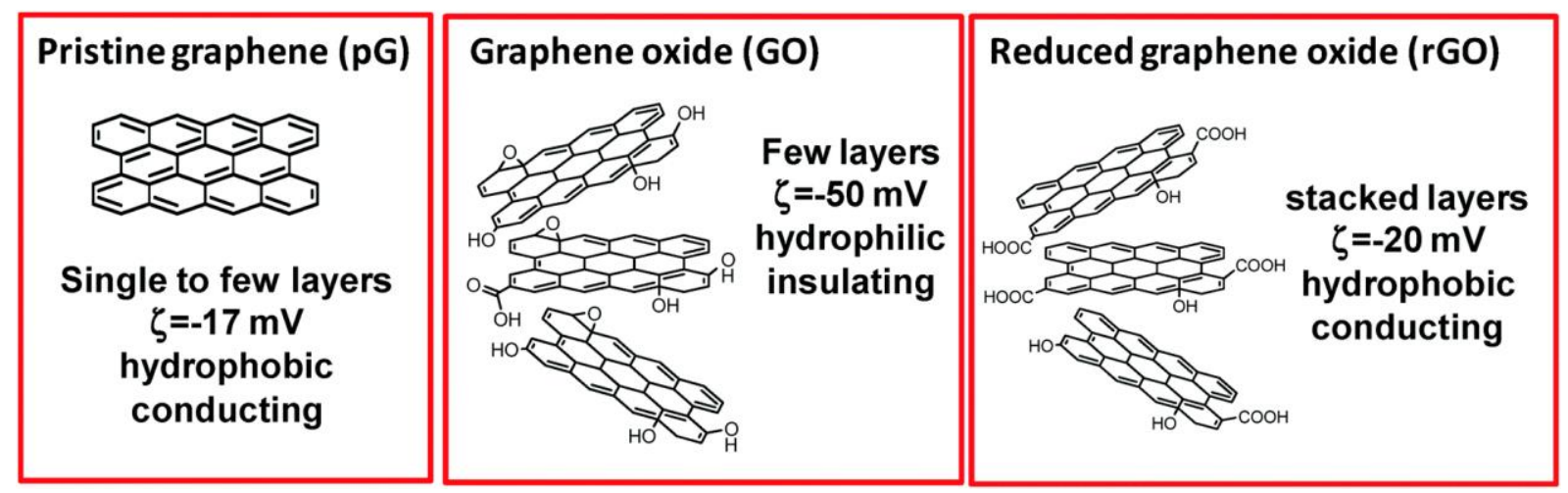

Fig. 2 Graphene family.

Despite intense interest in graphene, widespread implementation of graphene is yet to occur. Micromechanical exfoliation fails in producing graphene in large quantities. In addition, exfoliated graphene has the tendency to restack to form graphite through $\pi-\pi$ stacking and van der Waals interactions if the sheets are not well separated from each other. This all calls for the necessity to develop, on the one hand, alternative production processes and, on the other hand, to reduce and control aggregation of single-layer graphene into multilayered structures. Organic chemistry and surface chemistry offer the needed toolboxes to meet both demands. The first success in dissolving graphite dates back to the end of the 19th century, when Hummer, Offeman and Staudenmaier showed that treating graphite with strong acids afforded products referred to as graphite oxide. ${ }^{29}$ Subsequent mechanical/chemical or thermal exfoliation of graphite oxide forms graphene oxide (GO) sheets. GO was found to swell once in contact with water, an indication for its hydrophilic nature. Indeed, the surface of GO is highly oxygenated, bearing hydroxyl, epoxide, diol, and carbonyl functional groups allowing GO to readily swell and disperse in water (Fig. 2). The negatively charged oxygen species help in addition to disperse graphene oxide as a single sheet by providing electrostatic repulsion and solvation. The drawback is that the presence of oxygen groups on the basal plane of graphene disrupts the $\pi$-conjugation, as a result of which GO is insulating.

The oxygen-containing functionalities on the GO surface can be removed through reduction procedures. This reduction of GO to reduced graphene oxide (rGO) (Fig. 2) can be achieved through chemical (e.g. hydrazine monohydrate, sodium borohydride, hydroquinone), thermal, photochemical and other means. ${ }^{29-47}$ Hydrazine monohydrate is still the most widely used, mainly due to its strong reduction activity to eliminate most oxygen-containing functional groups of GO and its ability to yield stable rGO aqueous dispersions. ${ }^{48}$ However, with hydrazine as the reducing agent, its residual trace may strongly decrease the performance of rGO-based devices. In addition, hydrazine is a highly toxic and potentially explosive chemical. To avoid using hydrazine, many environmentally friendly and high-efficiency reductants have been developed and used for the reduction of GO, including vitamin $\mathrm{C},{ }^{49,50}$ amino acids, ${ }^{50}$ reducing sugar ${ }^{51}$ alcohols,${ }^{52}$ hydroiodic acid, ${ }^{53}$ reducing metal powder, ${ }^{54,55}$ sodium citrate, ${ }^{56}$ tea,${ }^{57}$ lysozyme, ${ }^{58}$ dopamine, ${ }^{59,60}$ etc. Independent of the reduction method used, the resulting nanocarbons differ from graphene, since the structural integrity and hence the electronic properties are altered when compared to pristine graphene. The chemically derived rGO is however both versatile and scalable, offers the greatest ease for functionalization, and is adaptable to a wide variety of applications.

DOI: 10.1039/C6TB01647B - Journal: Journal of Materials Chemistry B: Materials for biology and medicine - Post-print 
In light of this, in this review, the different approaches for combating bacterial infections using graphene-based materials, namely graphene oxide (GO), reduced graphene oxide (rGO) and their composites, will be presented. The importance of surface functional groups, size and shape of graphene will be pointed out and will be discussed in depth. In terms of potential interaction with bacteria, the reduced conductivity of GO and rGO is not necessarily detrimental. The presence of different surface functions has the additional advantage of tuning the interaction with bacteria through the incorporation of other chemical functions or molecules. In order to get an overview of some of the past and present findings on the antibacterial and bacteriostatic properties of graphene, GO, rGO and their composites, in the following the most important works in this field will be discussed.

\section{Bactericidal character of pristine graphene (pG), graphene oxide (GO), and reduced graphene oxide (rGO)}

\subsection{Interaction in suspensions}

3. The presence of defects in rGO and GO alters heavily their conductivity and electronic properties, but also their overall physico-chemical properties (Fig. 2). It is thus not surprising that the interaction with bacteria is also influenced by the type of graphene material investigated.

4. In contrast to pristine graphene, with limited or no oxygen functions, GO bears oxygen functional groups on the basal planes and edges resulting in mixed $\mathrm{sp}^{2} / \mathrm{sp}^{3}$ hybridized carbon domains. Depending on the synthetic procedure, it contains a certain number of water molecules intercalated between the oxidized sheets and variable oxygen containing functionalities such as hydroxyl, ether, and carboxylic acid functions. The oxygen content is usually rather high, typically characterized by a $\mathrm{C} / \mathrm{O}$ ratio $<2.5$. Reduction of GO to $\mathrm{rGO}$ results in a material that resembles pristine graphene, but lacks the perfect crystallinity of intact graphene, inducing strain on both in-plane and out-of-plane deformations. ${ }^{61}$ rGO is hydrophobic and tends to aggregate via $\pi-\pi$ stacking. It is commonly believed that bacteria adsorption is rapid and strong on hydrophobic surfaces, while adhesion on hydrophilic substrates follows a model of reversible adhesion as proposed by Marshall. ${ }^{62}$ The chemical nature will be thus of high importance for the manner in which bacteria interact with surfaces. Surface charges are in addition known to influence bacterial adhesion. While pristine graphene has an overall neutral surface charge, GO as well as rGO exhibit negative surface charges which can be as negative as $-50 \mathrm{mV}$. Besides these chemical variations between the different graphene-based materials, the size of the sheets can vary from micrometer to nanometer structures. For instance, graphene disks in the size range of 2-20 $\mathrm{nm}$ have been commonly named as graphene quantum dots (GQDs). They are fluorescent due to quantum confinement effects, surface defects and zigzag edges. GQDs are composed mainly of $\mathrm{sp}^{2}$ hybridized carbon and are crystalline. The wide range of size and shape will certainly have an impact on the bactericidal character of the graphene structure as well as on cell growth. ${ }^{63-71}$ Finally, carbon dots (C-dots), spherical carbon particles with a size less than $10 \mathrm{~nm}$ and composed mainly of $\mathrm{sp}^{3}$ hybridized carbon which are usually amorphous, have to be added to the list of carbon materials investigated for their antibacterial activity.

DOI: 10.1039/C6TB01647B - Journal: Journal of Materials Chemistry B: Materials for biology and medicine - Post-print 
5. While numerous studies investigated the interaction of bacteria with GO and rGO nanosheets in suspension (Table 1 $)^{13,72-83}$ and revealed the loss of bacterial cell viability in a concentration and time dependent manner, with a greater loss of viability of Grampositive bacteria, it is the initial work by Liu et al. that shed light on the antibacterial activity of a family of related material dispersions, including graphite, graphite oxide, GO and rGO, using Gram-negative bacteria (E. coli) as a model (Fig. 3).${ }^{13}$ Under otherwise similar conditions and incubation times, GO dispersions exhibited the highest antibacterial activity, followed by rGO, graphite and graphite oxide (Fig. 3A). SEM images of E. coli cells before and after incubation with GO for $2 \mathrm{~h}$ showed that the bacteria are flattened, have lost their cell integrity and are wrapped by a thin layer of GO. In contrast, E. coli cells were embedded in large rGO aggregates. This underlines that aggregation/dispersion and the lateral dimensions of graphene-based materials play an important role in the antibacterial avidity of graphene-based materials. ${ }^{13,72}$ While no superoxide radical anion $\left(\mathrm{O}_{2}{ }^{-}\right)$induced reactive oxygen species production was detected, the materials could oxidize glutathione, which serves as a redox state mediator in bacteria. Conductive rGO and graphite showed higher oxidative capacities than the insulating GO. These results suggested that antimicrobial actions are contributed by both membrane and oxidative stress involving three steps: (i) cell deposition on graphene materials, (ii) membrane stress caused by the direct contact with sharp nanosheets, and (iii) superoxide anion-independent oxidation. ${ }^{13}$ The same group showed, in addition, that the antimicrobial efficacy of dispersed GO evaluated against $\mathrm{E}$. coli cells exhibits strong lateral dimension dependency. ${ }^{72}$ For larger GO, viability loss increases sharply when compared to the smaller ones reaching complete inactivation $(>99 \%)$ in a time and concentration dependent manner. It was argued that large GO sheets cover cells more easily, and cells cannot proliferate once fully covered, resulting in the cell viability loss observed in the followed colony counting test. ${ }^{72}$ However, oxidative stress mediated by production of reactive oxygen species (ROS) is the only possible antibacterial mechanism of the graphene family (see Section 3 for a detailed discussion).

Table 1 Bactericidal character of pristine graphene (pG), graphene oxide (GO), and reduced graphene oxide (rGO)

\begin{tabular}{|c|c|c|c|}
\hline $\begin{array}{l}\text { Graphene } \\
\text { material }\end{array}$ & Bacterial cell model & Comments & Ref. \\
\hline GO & E. coli & $\begin{array}{l}69.3 \% \text { inhibition using plate } \\
\text { counting at }[\mathrm{GO}]=85 \mu \mathrm{g} \mathrm{mL}^{-1} \text {, loss } \\
\text { of cell integrity, no } \mathrm{O}_{2}{ }^{-} \text {- formation }\end{array}$ & $\frac{13}{13}$ \\
\hline GO & E. coli & $100 \%$ destruction at $5 \mathrm{mg} \mathrm{mL}^{-1}$ & $\underline{73}$ \\
\hline $\mathrm{GO} / \mathrm{rGO}$ & E. coli & $\begin{array}{l}98.5 \% \text { inhibition using plate } \\
\text { counting at }[\mathrm{GO}]=85 \mu \mathrm{g} \mathrm{mL}^{-1} \\
\text { loss of cell integrity; GO showed } \\
\text { higher antibacterial activity }\end{array}$ & $\frac{75}{7}$ \\
\hline GO & E. coli & $\begin{array}{l}\text { Interaction with } \mathrm{GO} \text { for } 48 \mathrm{~h} \text { results } \\
\text { in the formation of } \mathrm{rGO}\end{array}$ & 74 \\
\hline
\end{tabular}

DOI: 10.1039/C6TB01647B - Journal: Journal of Materials Chemistry B: Materials for biology and medicine - Post-print 


\begin{tabular}{|c|c|c|c|}
\hline $\mathrm{GO}$ & E. coli & $\begin{array}{l}\text { Large GO sheets show stronger } \\
\text { antibacterial activity over small } \\
\text { ones at }[\mathrm{GO}]<10 \mu \mathrm{g} \mathrm{mL}^{-1}\end{array}$ & $\frac{72}{7}$ \\
\hline $\mathrm{GO}$ & P. aeruginosa & $\begin{array}{l}100 \% \text { inhibition using plate } \\
\text { counting at }[\mathrm{GO}]=10^{2} \mu \mathrm{g} \mathrm{mL} \mathrm{mL}^{-1}\end{array}$ & $\frac{80}{1}$ \\
\hline $\mathrm{GO}$ & $\begin{array}{|lr|}\text { Streptococcus } & \text { mutans } \\
\text { Porphyromonas } & \text { gingivalis } \\
\text { Fusobacterium nucleatum } & \\
\end{array}$ & $\begin{array}{l}\text { Loss of cell integrity, intracellular } \\
\text { content leakage at }[\mathrm{GO}]=20-80 \\
\mu \mathrm{g} \mathrm{mL}-1\end{array}$ & 67 \\
\hline $\mathrm{GO}$ & $\begin{array}{l}\text { P. syringae/X. campestris pv. F. } \\
\text { graminearum/F. oxysporum }\end{array}$ & $90 \%$ killing at $[\mathrm{GO}]=500 \mu \mathrm{g} \mathrm{mL}^{-1}$ & 79 \\
\hline $\mathrm{GO}$ & $\begin{array}{l}\begin{array}{l}\text { Bacillus subtilis/Enterococcus } \\
\text { faecalis/Salmonella } \\
\text { coli }\end{array} \\
\end{array}$ & $\mathrm{MIC}=0.25 \mathrm{mg} \mathrm{mL}^{-1}$ & $\underline{81}$ \\
\hline rGO & $\begin{array}{|lr|}\text { E. } & \text { coli/Salmonella } \\
\text { typhimurium/Enterococcus faecalis }\end{array}$ & $\mathrm{MIC}=1-8 \mu \mathrm{g} \mathrm{mL^{-1 }}$ & 77 \\
\hline rGO & E. coli & $\begin{array}{l}88 \% \text { inhibition using plate } \\
\text { counting at }[\mathrm{rGO}]=175 \mu \mathrm{g} \mathrm{mL}\end{array}$ & $\underline{82}$ \\
\hline $\mathrm{pG} / \mathrm{GO} / \mathrm{rGO}$ & \begin{tabular}{|l|}
$\begin{array}{l}\text { Listeria monocytogenes Salmonella } \\
\text { enterica }\end{array}$ \\
\end{tabular} & $\begin{array}{l}{[\mathrm{GO}]=25 \mu \mathrm{g} \mathrm{mL} L^{-1} \text { and }[\mathrm{pG}]=250} \\
\mu \mathrm{g} \mathrm{mL}^{-1} \text { for full inhibition of } \\
\text { bacterial growth }\end{array}$ & $\frac{76}{3}$ \\
\hline pG/Tween 80 & Gut microbia & \begin{tabular}{|l}
$\begin{array}{l}\text { Oxidative stress, loss of cell } \\
\text { integrity }\end{array}$ \\
\end{tabular} & $\underline{78}$ \\
\hline G-QDs & E. coli/S. aureus & $\begin{array}{l}80 / 92 \% \text { inhibition using plate } \\
\text { counting at }[\mathrm{G}-\mathrm{QDs}]=200 \mu \mathrm{g} \mathrm{mL}^{-1}\end{array}$ & $\underline{83}$ \\
\hline
\end{tabular}

GO: graphene oxide; rGO: reduced graphene oxide; pG: pristine graphene; G-QDs: graphene quantum dots.

DOI: $10.1039 /$ C6TB01647B - Journal: Journal of Materials Chemistry B: Materials for biology and medicine - Post-print 
(A)
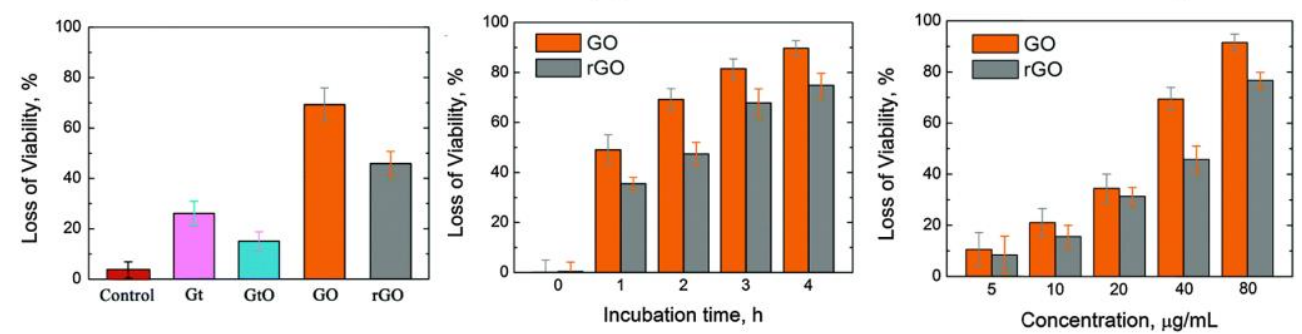

(B)

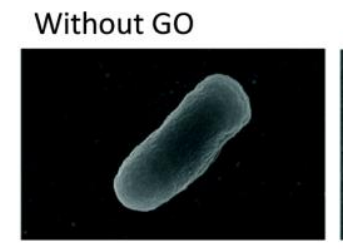

$\mathrm{GO}(40 \mu \mathrm{g} / \mathrm{mL}$ for $2 \mathrm{~h}) \quad \mathrm{rGO}(40 \mu \mathrm{g} / \mathrm{mL}$ for $2 \mathrm{~h})$

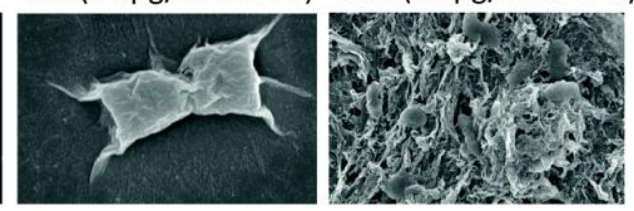

(C)

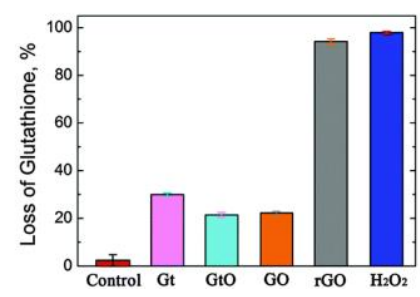

Fig. 3

(A) Viability of bacterial cells after incubation with different graphene-related nanomaterials such as graphite (Gt), graphite oxide (GtO), GO and rGO suspensions at different concentrations and times; (B) SEM images of E. coli in the absence and after incubation with $\mathrm{GO}$ and $\mathrm{rGO}$ dispersions $\left(40 \mu \mathrm{g} \mathrm{mL}^{-1}\right)$ for $2 \mathrm{~h}$; (C) loss of glutathione after in vitro incubation with graphite $(\mathrm{Gt})$, graphite oxide $(\mathrm{GtO}), \mathrm{GO}$ and $\mathrm{rGO}$ suspensions (reprint with permission from ref. 13).

The potential of wrapping E. coli by graphene nanosheets was also investigated by Akhavan et al. ${ }^{73}$ They found that the bacteria entrapped within the aggregated sheets were biologically disconnected from their environment, and do not proliferate. However, after removing the sheets from the surface of the microorganisms by sonication, the bacteria were reactivated and proliferated, i.e. they were alive within the aggregated graphene sheets at least for $24 \mathrm{~h} \cdot \underline{\mathrm{73}}$ These results suggest that graphene nanosheets may potentially serve as an encapsulating material for delivery of such microorganisms. The trapped alive bacteria could however be fully inactivated photothermally using near-infrared irradiation at $808 \mathrm{~nm}$. The same group also suggested that the interaction of GO with $\mathrm{E}$. coli under acidic conditions leads to the formation of rGO. $\stackrel{74}{ }$ In addition, it was demonstrated that exposing GO for $48 \mathrm{~h}$ to bacteria results in the reduction of GO. The reduction is believed to be due to the metabolic activity of the surviving bacteria through their glycolysis process. GO sheets act as adsorption sites for bacteria, while the reduced GO sheets exhibit an inhibition of the bacterial proliferation on their surface. $\underline{74}$

In line with the results by Liu et al., $\frac{13}{} \mathrm{Hu}$ et al. reported on the antibacterial activity of aqueous GO and rGO suspensions. ${ }^{75}$ Colony forming units ( $\mathrm{cfu}$ ) counting was used to assess the bactericidal effect of both materials. It was demonstrated that both graphene matrices effectively inhibit E. coli cell growth with $98.5 \%(\mathrm{GO})$ and $>90 \%(\mathrm{rGO})$ viability loss.

9

DOI: 10.1039/C6TB01647B - Journal: Journal of Materials Chemistry B: Materials for biology and medicine - Post-print 
As can be seen from Table 1, the large part of the literature focused on the antibacterial properties of graphene-based materials against E. coli while other bacterial strains were rarely investigated. Chawalibog and co-workers studied the interaction of different graphene materials (pristine graphene, GO, rGO) with food-borne bacterial pathogens Listeria monocytogenes and Salmonella enterica. The antibacterial activity decreased from graphene, for which a concentration as high as $250 \mu \mathrm{g} \mathrm{mL}^{-1}$ was needed to completely inhibit pathogen growth, to rGO with GO showing the highest antibacterial activity even at low concentration $(25 \mu \mathrm{g}$ $\left.\mathrm{mL}^{-1}\right) \cdot \underline{76}$

Krishnamoorthy et al. determined the minimum inhibitory concentration (MIC) of rGO nanosheets against E. coli, Salmonella typhimurium and Enterococcus faecalis. $\frac{77}{}$ MICs between 1 and $8 \mu \mathrm{g} \mathrm{mL}^{-1}$ were obtained, while a standard drug such as kanamycin showed MICs in the 64-128 $\mu \mathrm{g} \mathrm{mL}^{-1}$ range, with the lower MIC values being for Gram-negative bacteria.

Xie et al. recently studied the influence of pristine graphene dispersed in Tween 80 on microbial communities and antibiotic resistance genes in mouse guts. $\underline{78}$ The results showed that graphene exposure increased biodiversity of the gut microbiota and changed their community. The influence of graphene on gut microbiota was attributed to the fact that graphene could induce oxidative stress and damage to cell membrane integrity.

He et al. exploited the antibacterial activity of GO to kill dental pathogens such as Streptococcus mutans, Porphyromonas gingivalis and Fusobacterium nucleatum. $\frac{67}{}$ TEM images revealed that the cell wall and the membrane of the bacteria lost their integrity and the intracellular contents leaked out after GO treatment at concentrations of $20-80 \mu \mathrm{g} \mathrm{mL}{ }^{-1}$.

Han and co-workers conducted studies on the antimicrobial activity of GO against P. syringae, $\mathrm{X}$. campestris pv. and two fungal pathogens such as F. graminearum and F. oxysporum. At a concentration of $500 \mu \mathrm{g} \mathrm{mL} \mathrm{mL}^{-1}$, GO showed a powerful effect on the reproduction of all 4 pathogens. $\frac{79}{}$

In the case of $\mathrm{P}$. aeruginosa,,$\underline{80}$ vaguely better antibacterial activity was observed for rGO. Most importantly, exposure to $\mathrm{GO}$ and $\mathrm{rGO}$ induced significant production of $\mathrm{O}_{2}{ }^{-}$, in contrast to $\mathrm{E}$. coli. $\underline{13}$

\subsection{Interaction with graphene-coated surfaces}

A number of research groups have investigated the antimicrobial and anti-biofilm forming activity of graphene sheets supported on a wide variety of surfaces. There is a great interest in producing such interfaces as biofilm formation occurs just about on any surface, from copper pipes to medical catheters and implants, resulting in contamination of water and food supplies as well as persistent infections in medical settings. Even cavities in teeth are the unwelcome result of bacterial colonies. One of the first studies on the interaction of bacteria with graphene are those by Akhavan and Ghaderi $\frac{84}{}$ and $\mathrm{Hu}$ et al. ${ }^{75}$ Akhavan et al. ${ }^{84}$ coated GO on stainless steel substrates through electrophoretic deposition from a suspension containing $\mathrm{Mg}^{2+}-\mathrm{GO}$ nanosheets resulting in GO nanowells (GONWs) with a significant amount of exposed edges (Fig. 4Aa). Reduction of the GONWs by hydrazine vapor did not change the morphology, but

DOI: 10.1039/C6TB01647B - Journal: Journal of Materials Chemistry B: Materials for biology and medicine - Post-print 
resulted in a significant reduction of the $\mathrm{C}-\mathrm{O}, \mathrm{C} \quad \mathrm{O}$ and $\mathrm{O} \quad \mathrm{C}-\mathrm{OH}$ functions as evidenced by the $\mathrm{C}_{1 \mathrm{~s}}$ XPS core level spectra of both graphene structures (Fig. 4Ab). Reduced GONWs exhibited lower survival rates towards S. aureus (5\%) and E. coli (16\%) when compared to GONWs (26 and 41\%, respectively; Fig. 4Ac). The sharpened edges of reduced GONWs are believed to provide stronger contact points with the bacterial cell membrane, resulting in enhanced membrane damage and cell death. The graphene structures exhibited stronger antibacterial activity against $\mathrm{S}$. aureus than E. coli due to higher resistance of E. coli bacteria against the direct interaction with the edge of the nanowalls. Indeed, as a Gram-positive bacterium, S. aureus is constituted by a peptidoglycan layer with a thickness ranging from 20 to $80 \mathrm{~nm}$ without an outer membrane, while the Gram-negative E. coli has a much thinner peptidoglycan layer (1-8 $\mathrm{nm})$ and possesses an additional outer membrane.

(A)

(a)

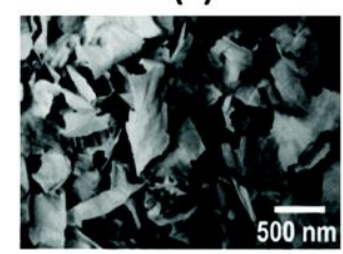

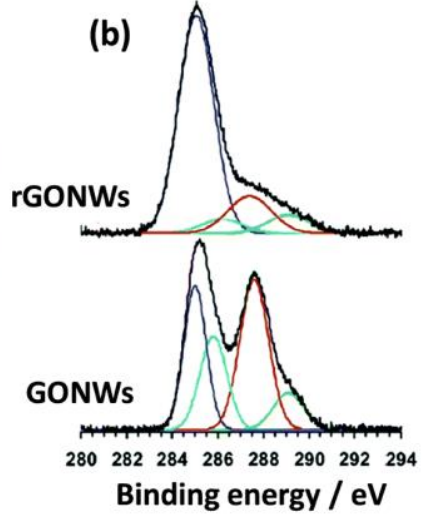

(a)

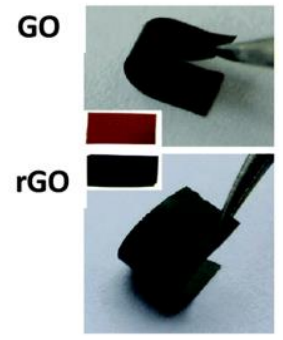

(a)

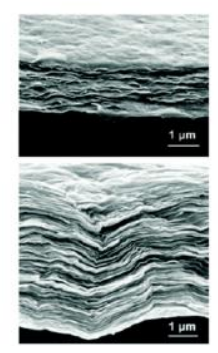

(c)

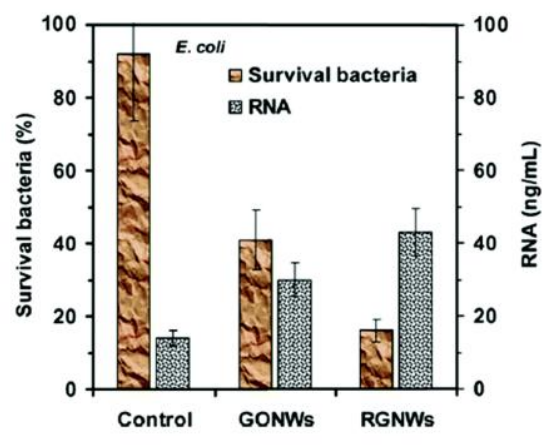

(B)

\section{(b)}

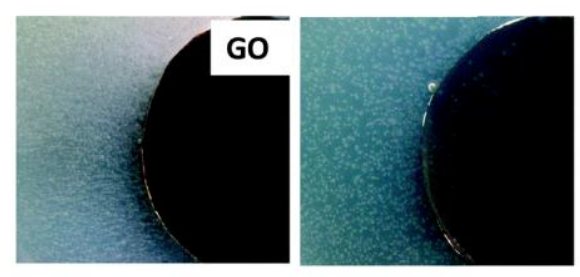

Fig. 4 (A) (a) SEM images of electrophoretically deposited GO nanowells, (b) peak deconvolution of $\mathrm{C}_{1 \mathrm{~s}}$ core level XPS spectra of GONWs and reduced GONWs together with (c) cytotoxicity of both materials to E. coli (reprint with permission from ref. 84). (B) (a) Photographs of freestanding, flexible GO and rGO paper, (b) photographs of E. coli grown on GO and rGO paper (reprint with permission from ref. 75).

The antibacterial efficacy of GO and rGO nanosheets on freestanding paper was assessed by $\mathrm{Hu}$ et al. (Fig. 4Ba) $\frac{75}{}$ No visible bacterial growth appeared on the GO paper, whereas a small number of E. coli colonies were visible on the rGO paper after overnight incubation (Fig. 4Bb).

DOI: $10.1039 /$ C6TB01647B - Journal: Journal of Materials Chemistry B: Materials for biology and medicine - Post-print 
This is in contrast to the results of Akhavan and Ghaderi. $\stackrel{84}{ }$ However, in the results reported by $\mathrm{Hu}$ et al.,$\underline{75} \mathrm{GO}$ and rGO lay relatively flat on the surface with only a few edges oriented away from the interface. More recently, Elimelche et al. pointed out that, in addition, the size effects are also important with a 4-fold increase in the antimicrobial activity when the GO sheet area decreased from 0.65 to $0.01 \mu \mathrm{m}^{2} . \underline{6}$

According to Zhao et al., GO can be fixed onto cotton fabrics through direct adsorption or crosslinking. The GO fabric eliminated more than $90 \%$ of an E. coli cell population even after being washed 100 times. $\frac{85}{}$

Ruiz et al. reported results that contradicted the previous studies, using coated sterile PVDF filters with a GO colloidal suspension. $\frac{63}{6 O}$-coated filters lacked bacteriostatic activity and even supported E. coli growth. It is likely that this preparation results on GO lying flat on the substrate with few exposed edges. From these studies, it is clear that the antibacterial activity of structurally flat graphene is an interesting avenue to investigate.

GO formed on PET substrates by the Langmuir Blodgett technique results in flat sheets. The observed antibacterial activity was found to be layer dependent, with increasing number of layers resulting in increased antibacterial properties: three layers of GO displayed the most efficient $(89 \%)$ inactivation. $\underline{86}$

Li et al. evaluated the interaction of graphene films deposited on copper, germanium and silica with S. aureus and E. coli. $\frac{87}{}$ Both species were dissociated from the graphene surface and recultivated in solid growth media. No bacterial growth was observed for graphene on $\mathrm{Cu}$ and $\mathrm{Ge}$, while in the case of graphene on $\mathrm{SiO}_{2}$ colony growth was observed, indicating that graphene on conducting and semiconducting surfaces is bactericidal. The following section will look at this from a mechanistic point of view in more detail.

\section{Antibacterial mode of actions of graphene nanostructures}

While several studies have demonstrated that pristine graphene and its derivatives possess antibacterial properties, the mechanism by which these antimicrobial properties arise continues to be the subject of debate. $\frac{68,70,88}{}$ This is related to the rich and complex graphene and graphenecoated interfaces. Surface charge, hydrophobicity and roughness are highly dependent on the type of graphene derivative used and have important impacts on the antimicrobial properties of graphene. As the interaction of bacteria with graphene is in addition dependent on the orientation of the surface relative to the bacteria, the way graphene is deposited onto surfaces can influence the antimicrobial character significantly. A few mechanisms have been suggested to explain the antibacterial mode of action of graphene such as production of reactive oxygen species, $\frac{77}{}$ oxidative stress $\frac{13,80,89}{}$ or vigorous extraction of large amounts of phospholipids from the membrane of the bacteria under consideration (Fig. 5). $\underline{90}$ The morphological changes of E. coli exposed to GO nanosheets have been visualized by Tu et al. using TEM experiments. ${ }^{90} \mathrm{Fig}$. $\underline{5 \mathrm{~A}}$ depicts a TEM image of the cell morphology of E. coli incubated with GO $\left(100 \mu \mathrm{g} \mathrm{mL}^{-1}\right)$ at $37{ }^{\circ} \mathrm{C}$ for $2.5 \mathrm{~h}$. While E. coli can tolerate GO nanosheets for a short period of time at low concentrations, the E. coli cells lose their cellular integrity after $2.5 \mathrm{~h}$. The cell membranes are severely damaged and some are missing their cytoplasm entirely (Type A in Fig. 5A). Next to the damage of cell membranes, some bacteria display lower surface phospholipid density (Type $\mathrm{B}$ in Fig. 5A), which eventually results in a loss of cell membrane integrity. The lipid extraction 12

DOI: 10.1039/C6TB01647B - Journal: Journal of Materials Chemistry B: Materials for biology and medicine - Post-print 
mechanism was further confirmed by simulating the interaction between GO and membranes. Fig. 5B exhibits a representative configuration of GO interaction with both the outer and inner E. coli membranes showing the extraction of phospholipids by the GO nanosheets. The main driving force stems from the strong van der Waals interactions between the GO nanosheets and the membrane lipids. Once extracted, hydrophobic interaction plays a dominant role, where the lipid hydrophobic tails spread out mainly on the unoxidized hydrophobic regions of GO, while the hydrophilic head groups prefer to contact polar oxide functions via favorable electrostatic interactions. It is thus concluded that both the severe graphene insertion and destructive lipid extraction induced severe membrane stress and significantly reduced cell viability, a process that is concentration dependent and increases with increasing graphene lateral size. $\underline{90}$
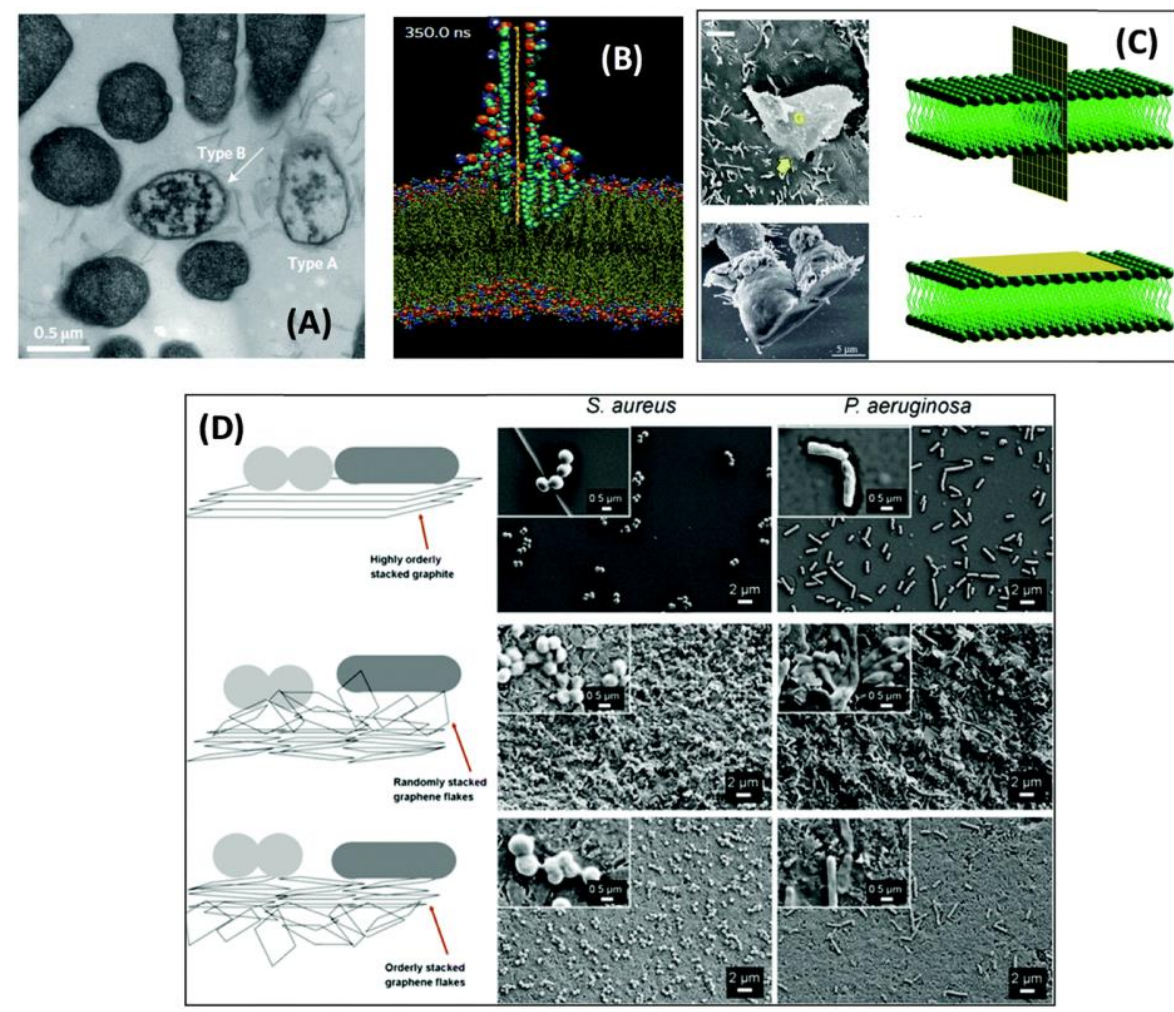

Fig. 5 (A) Morphological changes of E. coli exposed to GO $\left(100 \mu \mathrm{g} \mathrm{mL} \mathrm{L}^{-1}\right)$, TEM images of E. coli after $2.5 \mathrm{~h}$ incubation at $37^{\circ} \mathrm{C}$, arrows indicate the Type $\mathrm{B}$ mechanism, where GO nanosheets extract phospholipids from the cell membrane, in the Type A mechanism GO nanosheets cut off large areas of the membrane surface; (B) simulation of lipid extraction of GO nanosheets: hydrogen (white), oxygen (red), nitrogen (dark blue), carbon (cyan), phosphorus (orange) (reprint with permission from ref. 90); (C) influence of GO size on the interaction with the cell membrane: near-perpendicular penetration at a corner (yellow arrow) with micrometer sized GO, or parallel attachment and spreading of GO nanosheets (reprint with permission from ref. 92); (D) influence of the orientation of GO on bactericidal activity (reprint with permission from ref. 94).

Indeed, this mechanism, sometimes referred to as "insertion mode of action", based on the action of the sharp edges of graphene nanosheets, which act as knives to cut through cell membranes of bacteria, resulting in the leakage of intracellular substrates causing eventually cell death has been proposed by several other studies. ${ }^{84,91}$ Akhavan reported that both GO and 13

DOI: 10.1039/C6TB01647B - Journal: Journal of Materials Chemistry B: Materials for biology and medicine - Post-print 
rGO exhibit bactericidal behavior towards Gram-negative and Gram-positive bacteria arising from the direct contact of the bacterial cell wall with the sharp edges of GO and $\mathrm{rGO} .{ }^{84} \mathrm{Li}$ et al. suggested that the bacterial action occurred through a spontaneous localized piercing of the bacterial cell wall by the sharp edges and corner sites present on the graphene nanosheets, followed by the full penetration of the graphene through the lipid bilayer. ${ }^{91} \mathrm{Yi}$ et al. further demonstrated that insertion of graphene sheets in the lipid bilayer was size-dependent, where the micrometer sized graphene preferred to adopt a near-perpendicular configuration with respect to the cell wall, while nanosheets were required to adopt a position that was parallel to the lipid bilayer (Fig. 5C) ${ }^{92}$ This was driven by the preferential attraction between the hydrocarbon tails of the lipids and the lipophilic flat surface of graphene, allowing the graphene to sink in between the lipid tails, embedding the graphene nanosheets in the cell membrane. Dallavalle on the other hand showed that the smaller the graphene sheets are, the more freely they could diffuse into the lipid membrane in a preferential perpendicular orientation, while larger nanosheets prefer to arrange themselves across the membrane, embedding themselves in the more lipophilic section of the cell membrane. ${ }^{93}$

More recently, the antimicrobial behavior of pristine graphene was investigated by Pham et al. in an attempt to further advance the current knowledge pertaining to graphene cytotoxicity using both experimental and computer simulation. ${ }^{94}$ They validated that the density of graphene edges was the principal parameter that contributes to the antibacterial behavior, which results in the formation of pores in the bacterial cell walls, causing a subsequent osmotic imbalance and cell death.

An additional possible mechanism was proposed by Luan et al. ${ }^{95}$ They demonstrated that the flat face of graphene, being lipophilic, disrupts the protein-protein bonding in the cell membrane, leading to the destabilization of the three-dimensional structure of the protein, causing its functional failure. The bacteria showed a self-killing effect, where the bacterial metabolic activity increased causing the GO to be reduced to a form of graphene that was bactericidal via a glycolysis process. ${ }^{74}$

Indeed, next to the insertion mode of action, another concept stipulates that the destructive effect of graphene on the bacterial membrane is induced by "direct contact" of the bacterial cell membrane with the basal plane of graphene. ${ }^{86,87,89}$ We have investigated recently the adhesion behavior of two different E. coli strains, UTI89 and LF82, to gold interfaces coated with CVD graphene. As seen from SEM images in Fig. 6A, no morphological changes or membrane damage of the bacteria occurred, demonstrating that such interfaces possess no antibacterial properties. Adherent and invasive E. coli such as LF82 bacteria can in contrast easily proliferate into biofilms.

DOI: 10.1039/C6TB01647B - Journal: Journal of Materials Chemistry B: Materials for biology and medicine - Post-print 
(A)

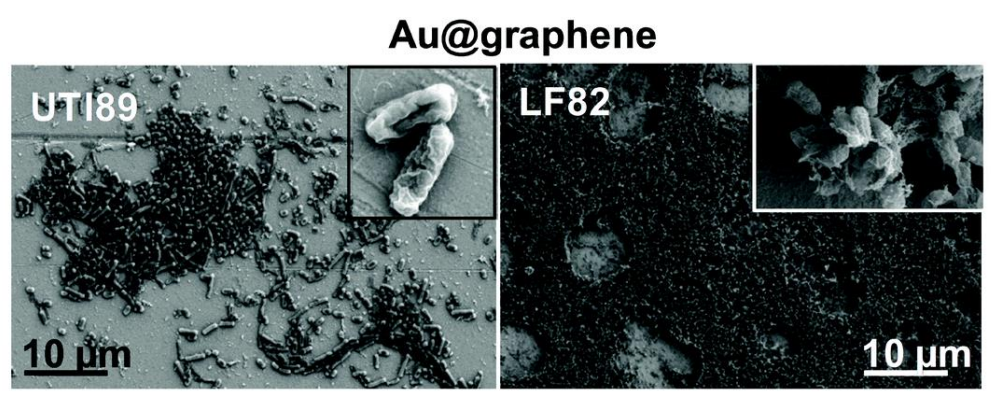

(B)
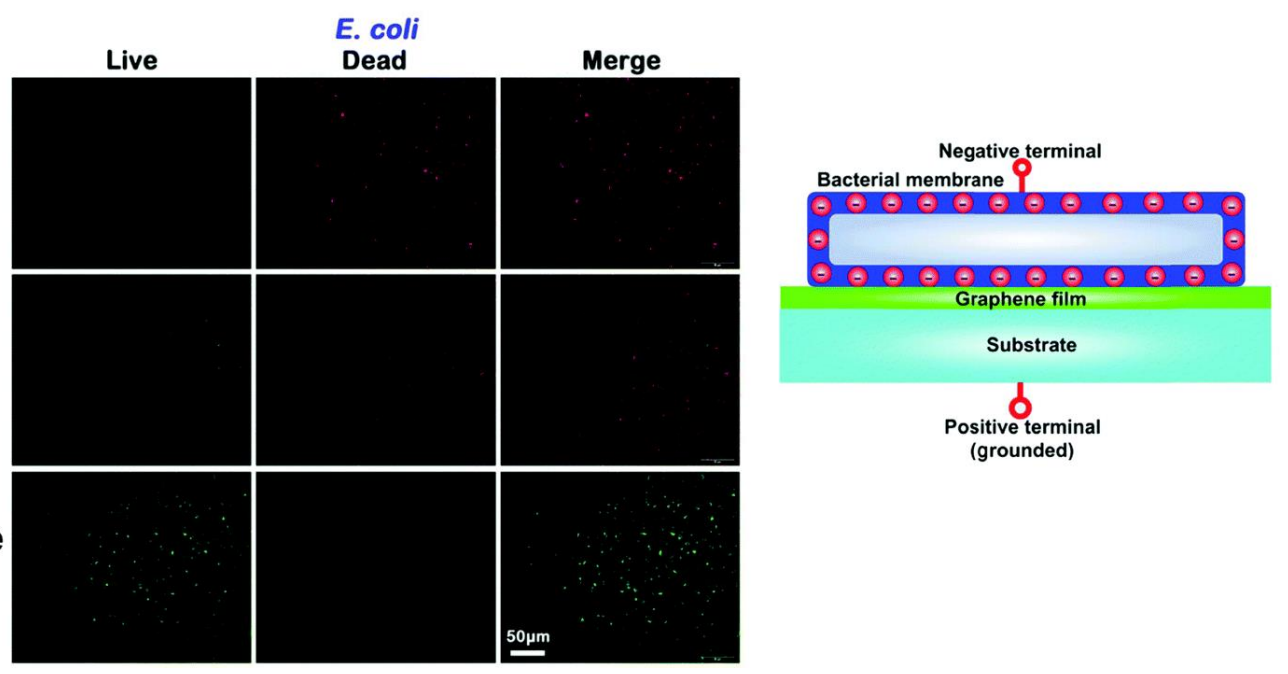

$\mathrm{SiO}_{2} @ g r a p h e n e$

Fig. 6 (A) SEM images of E. coli UTI89 and LF82 seeded on gold coated with CVD graphene $\left(24 \mathrm{~h}\right.$ at $37^{\circ} \mathrm{C}$ ) at low and high magnifications (insets); (B) fluorescence images showing the viability of bacteria after $24 \mathrm{~h}$ incubation over different interfaces, visualized by staining with a LIVE/DEAD bacterial viability kit (live bacteria are green, dead ones are red) together with the proposed mechanism of the observed phenomenon (reprint with permission from ref. 87).

Li et al. showed that the destructive effect of graphene coated surfaces is related to the electronic properties of the substrate (Fig. 6B) ${ }^{87}$ Large-area graphene films on $\mathrm{Cu}$ and $\mathrm{Ge}$ inhibited bacterial growth and resulted in bacterial death, while the proliferation of bacteria cannot be restricted by graphene films on $\mathrm{SiO}_{2}$. The easy transfer of electrons was believed to be the underlying reason, as for both $\mathrm{Cu}$ and $\mathrm{Ge}$, the graphene-on-substrate junctions can act as an electron pump and electrons are steadily pumped away from the microbial membrane producing oxidative stress in the membrane. Indeed, Mangadlao et al. demonstrated that the antibacterial efficiency of graphene is not dependent on its sharp edges, but depends upon the contact that takes place between the GO basal plane and E. coli cells. ${ }^{86}$ They found that $89 \%$ E. coli killing efficiency could be achieved using a GO film that had been fabricated using the LangmuirBlodgett deposition method; the technique limits the extent of exposure of sharp edges present on the GO to the bacteria. This is confirmed by the work of Hui and coworkers, who demonstrated that masking the GO basal plane decreased the antimicrobial efficiency of the GO nanosheets by decreasing the extent of direct contact with the bacteria. ${ }^{89}$

DOI: 10.1039/C6TB01647B - Journal: Journal of Materials Chemistry B: Materials for biology and medicine - Post-print 


\section{Bactericidal character of functional graphene and graphene nanocomposites}

The broad antimicrobial properties of graphene based materials are well established. For several application-driven purposes, it has become imperative to enhance the biocompatibility as well as the robustness of graphene based materials, while sustaining their antimicrobial properties. The presence of amine and quaternary ammonium groups is known to enhance the antibacterial properties of nanostructures, and several efforts for their integration into graphene based materials have been undertaken. In most cases, this was achieved by using polymers such as chitosan, $\underline{96}$ polyethyleneimine (PEI) $\underline{97}$ or poly(L-lysine) (PLL).$\underline{65}$

\subsection{From graphene based polymer nanocomposites and hydrogels to membranes}

A number of researchers have investigated the application of graphene-based matrices that contain polymers (e.g. chitosan, poly(vinyl alcohol), polyamide, polyethyleneimine, etc.) for enhancing the antimicrobial effects. ${ }^{65,88,97-118}$ In addition, current efforts in the formulation of polymer-graphene nanocomposites have resulted, in several cases, in the development of graphene based membranes, one of the most significant marketable products for application in disinfection, gas separation or water desalination. ${ }^{107,116-119}$ Lately, Hui and co-workers reported in this respect an antibacterial surface based on a polyelectrolyte-stabilized rGO sheet that kills airborne bacteria on contact upon minutes of solar near-infrared (NIR) irradiation. The observed activity was reported to be retained even when the film was placed underneath a piece of pork tissue, indicating that solar light in the near-infrared region plays a dominant role in the observed activity. ${ }^{119}$

Electrostatic interaction between the negatively charged carboxylic acid groups of GO and inherently anti-bacterial polymers such as those containing amine or quaternary ammonium groups has proven to be particularly an easy way to increase the antibacterial properties of graphene materials. Lee and co-workers reported on the integration of poly(L-lysine) (PLL) onto GO and $\mathrm{rGO} .{ }^{65}$ This composite material functions as an antibacterial agent, but at the same time promotes the growth of human cells (Fig. 7A). They also modified the composite to boost the amount of cationic charges through covalent attachment of diazonium salts, which resulted in a further decrease in cell adherence. A flexible polyurethane composite, prepared by incorporation of polyethyleneimine-modified $\mathrm{rGO}$, was proposed recently by Tang to enhance bacterial anti-adhesive properties when compared to pure polyurethane and GO-polyurethane, due to the high density of amine groups in the PEI chains. ${ }^{97}$

DOI: 10.1039/C6TB01647B - Journal: Journal of Materials Chemistry B: Materials for biology and medicine - Post-print 
(A)

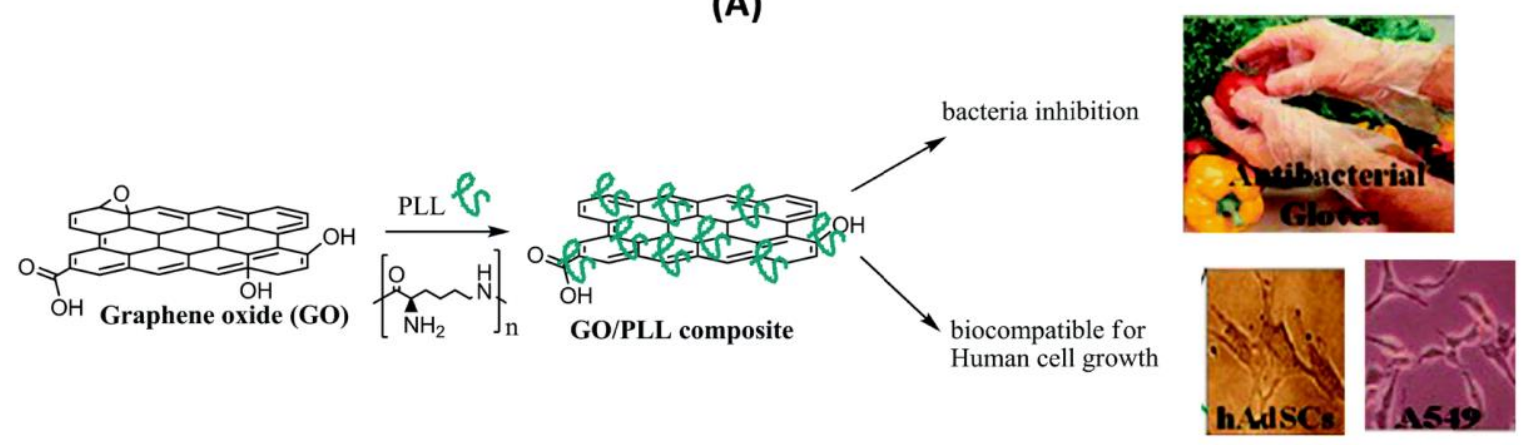

(B)

(a)

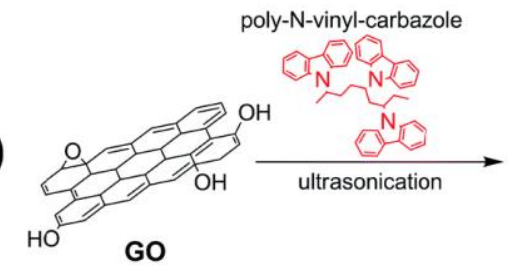

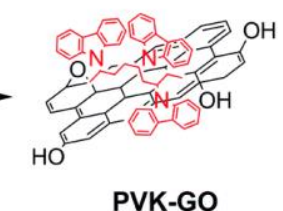

PVK-GO
(C)

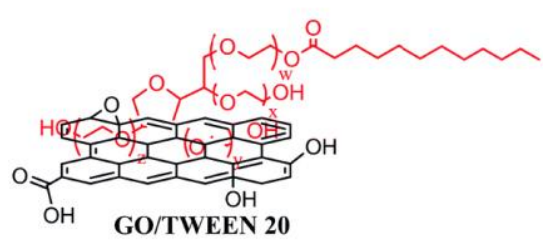

GO/TWEEN 20

(b)
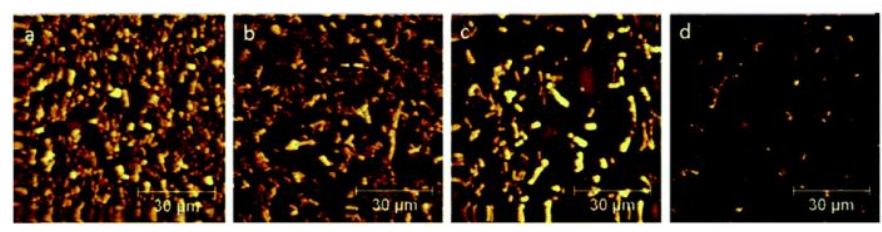

Fig. 7 (A) Chemical modification of GO with poly(L-lysine); the GO/PLL composite can be used as an antibacterial agent, but at the same time promotes the growth of human cells (reprint with permission from ref. 65); (B) (a) formation of poly-N-vinyl-carbazole (PVK) modified GO, (b) AFM images of E. coli biofilms after $48 \mathrm{~h}$ growth on bare ITO (a), PVK-modified ITO (b), GO-modified ITO (c) and PVK-GO modified ITO (d) (reprint with permission from ref.

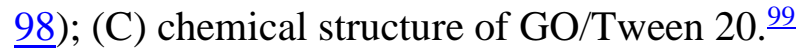

GO-based bactericidal hydrogels have to be added to this list as these scaffold materials have attracted much attention as efficient matrices for immobilization and encapsulation of biomolecules. ${ }^{120,121}$ One of the first attempts is that by Wang et al., ${ }^{121}$ employing a biocompatible agarose polysaccharide where the formed hydrogel resulted in a full reduction of bacterial growth. Incorporation of commercial preservatives such as benzalkonium bromide cationic surfactants into GO resulted in hydrogels with strong bactericidal activity against a broad spectrum of pathogens. ${ }^{120}$

The efficiency of polyvinyl-N-carbazole (PVK) modified GO against E. coli, C. metallidurans, B. subtilis and R. opacus was demonstrated by Mejeas (Fig. 7Ba). ${ }^{98}$ The formed PVK-GO matrix when exposed to bacterial cells inactivated significant proportions of bacteria with a greater loss of viability of Gram positive bacteria. Furthermore, biofilm formation was inhibited on PVK-GO modified ITO surfaces due to the bactericidal activity of PVK-GO (Fig. 7Bb). Park et al. found that free-standing paper, composed of TWEEN/graphene, prevented the binding of bacteria due to the presence of the surfactant. ${ }^{99}$ Cystamine modified GO was tested by Nanda et al. and MIC values of $1 \mu \mathrm{g} \mathrm{mL}{ }^{-1}$ against E. coli and Salmonella typhimurium, $6 \mu \mathrm{g}$ $\mathrm{mL}^{-1}$ against Enterococcus faecalis, and $4 \mu \mathrm{g} \mathrm{mL} \mathrm{m}^{-1}$ against B. subtilis were determined. ${ }^{88}$

DOI: $10.1039 /$ C6TB01647B - Journal: Journal of Materials Chemistry B: Materials for biology and medicine - Post-print 


\subsection{Other modified graphene matrices}

Sreeprasade et al. produced composite films consisting of GO and $\mathrm{rGO}$ modified with lactoferrin (Lf), a multifunctional glycoprotein of the transferrin family, and chitosan. ${ }^{64} \mathrm{~A}$ significant increase in cytotoxicity was observed due to the presence of lactoferrin with the greatest loss of cell viability with a combination of Lf and chitosan, due to the well-known bacteriostatic properties of chitosan. GO modified with lysozyme, one of the enzymes that catalyze the hydrolysis of bacterial cell walls, which also acts as a nonspecific immune molecule against the invasion of bacterial pathogens, was proposed recently as an antibacterial ultrafiltration membrane against E. coli. ${ }^{116}$

Kanchanapally et al. showed furthermore that a 3D porous membrane comprising GO and nisin, an antimicrobial peptide, is capable of effectively identifying, separating and disinfecting water contaminated with methicillin resistant S. aureus (MRS) (Fig. 8A). ${ }^{122}$ The small membrane pore size (about $300 \mathrm{~nm})$ compared to the bacterial cell size $(1000 \mathrm{~nm})$ allows the retention of MRS and nearly complete water disinfection (Fig. 8B).

(A)

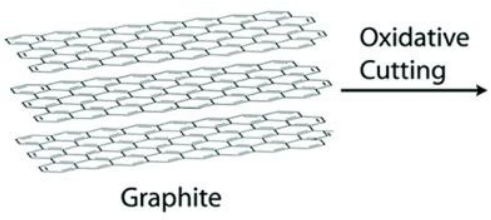

$\mathbf{A}$
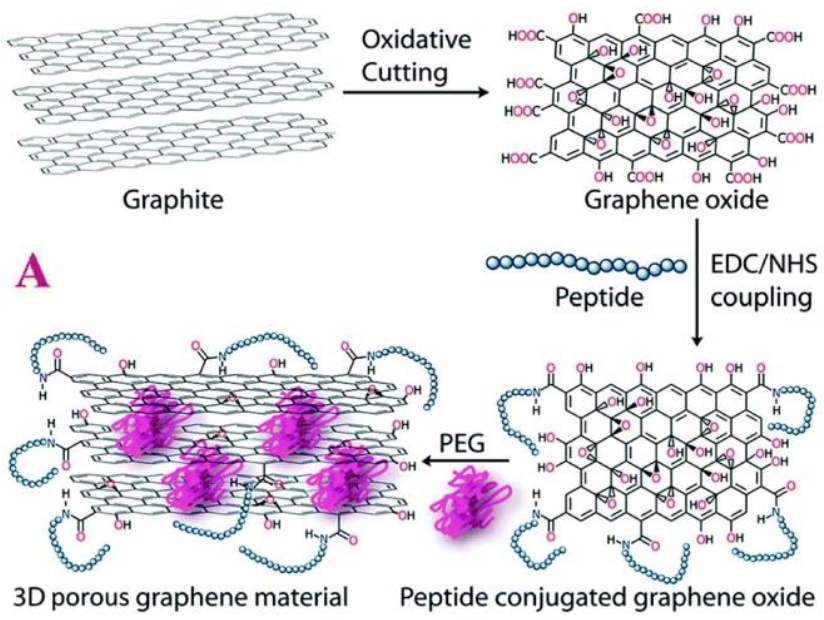

(B)

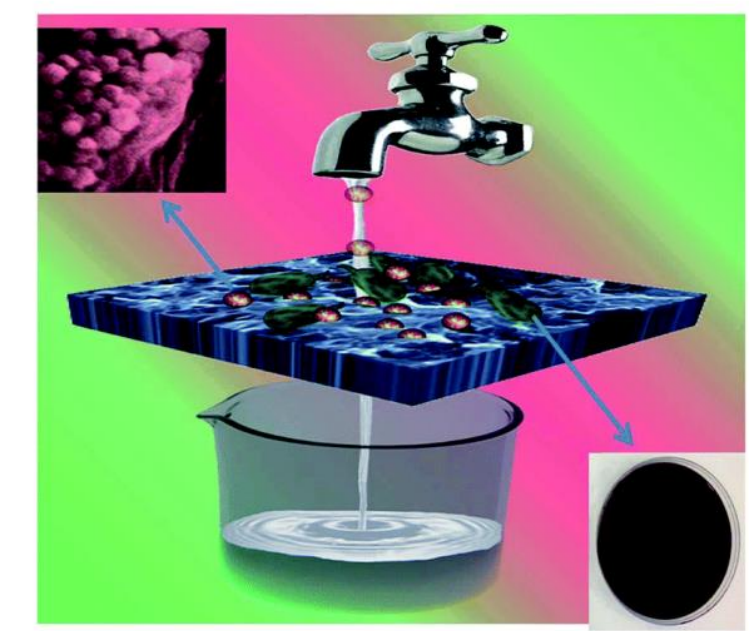

Fig. 8 (A) Synthetic procedure of a 3D graphene material modified with nisin antimicrobial peptide; (B) schematic representation showing the MDR pathogen separation and killing capability using a nisin conjugated porous graphene oxide membrane (inset: image of the membrane) (reprint with permission from ref. 122).

\subsection{Graphene-loaded with nanoparticles}

DOI: 10.1039/C6TB01647B - Journal: Journal of Materials Chemistry B: Materials for biology and medicine - Post-print 
he antibacterial activity of graphene and graphene based membranes can be further tuned by incorporating nanoparticles into the scaffolds. Promising results from several silver nanoparticle (Ag NP) based graphene materials $\frac{123-125}{2}$ resulted in an avalanche of reports on the antibacterial character of Ag NP loaded graphene nanocomposites, $\stackrel{126-128}{ }$ as seen from Table 2 . In addition to graphene loaded with Ag NPs, other metallic nanostructures such as gold nanoparticles (Au NPs) or copper nanoparticles ( $\mathrm{Cu}$ NPs), oxides including titanium oxide $\left(\mathrm{TiO}_{2}\right)$, zinc oxide $(\mathrm{ZnO})$ and iron oxide $\left(\mathrm{Fe}_{2} \mathrm{O}_{3}\right)$ and others such as $\mathrm{CuS}$ have been screened for their bactericidal properties and some examples are provided in Table 2.

Table 2 Antibacterial properties of nanoparticle decorated graphene matrices

\begin{tabular}{|c|c|c|c|}
\hline $\begin{array}{l}\text { Graphene } \\
\text { material }\end{array}$ & Bacterial cell model & Comments & Ref. \\
\hline \multicolumn{4}{|c|}{ Silver nanostructures } \\
\hline \begin{tabular}{|l|}
$\mathrm{GO}-\mathrm{Ag}$ \\
$\mathrm{NPs}$
\end{tabular} & E. coli & $\begin{array}{l}100 \% \text { inhibition at [GO-Ag NPs] }= \\
100 \mu \mathrm{g} \mathrm{mL}^{-1}\end{array}$ & 129 \\
\hline $\begin{array}{l}\mathrm{GO}-\mathrm{Ag} \\
\mathrm{NPs}\end{array}$ & E. coli & $\begin{array}{l}99.9 \% \text { inhibition at }[\mathrm{GO}-\mathrm{Ag} \mathrm{NPs}]= \\
3.2 / 6.4 \mu \mathrm{g} \mathrm{mL}^{-1}\end{array}$ & 130 \\
\hline $\begin{array}{l}\mathrm{GO}-\mathrm{Ag} \\
\mathrm{NPs}\end{array}$ & E. coli/P. aeruginosa & Agar diffusion assay $18 / 26 \mathrm{~mm}$ & $\underline{125}$ \\
\hline $\begin{array}{l}\mathrm{GO}-\mathrm{Ag} \\
\mathrm{NPs}\end{array}$ & S. aureus/B. subtilis & $\begin{array}{l}100 \% \text { inhibition with Agar diffusion } \\
\text { assay }\end{array}$ & 131 \\
\hline $\begin{array}{l}\mathrm{GO}-\mathrm{Ag} \\
\mathrm{NPs}\end{array}$ & E. coli/S. aureus & $\begin{array}{l}100 \% \text { inhibition at }[\mathrm{GO}-\mathrm{Ag} \mathrm{NPs}]=10 \\
\mu \mathrm{g} \mathrm{mL} \mathrm{mL}^{-1}\end{array}$ & 132 \\
\hline $\begin{array}{l}\mathrm{GO}-\mathrm{Ag} \\
\mathrm{NPs}\end{array}$ & E. coli/S. aureus & $\begin{array}{l}\text { Increasing Ag NPs increases growth } \\
\text { delay }\end{array}$ & 133 \\
\hline $\begin{array}{l}\mathrm{GO}-\mathrm{Ag} \\
\mathrm{NPs}\end{array}$ & E. coli/S. aureus & $\begin{array}{l}100 \% \text { inhibition at }[\mathrm{GO}-\mathrm{Ag} \mathrm{NPs}]=45 \\
\mu \mathrm{g} \mathrm{mL}-1\end{array}$ & 134 \\
\hline $\begin{array}{l}\mathrm{GO}-\mathrm{Ag} \\
\mathrm{NPs}\end{array}$ & Methicillin-resistant S. aureus & $\mathrm{MIC}=15 \mu \mathrm{g} \mathrm{mL} \mathrm{m}^{-1}$ & 135 \\
\hline $\begin{array}{l}\text { rGO-Ag } \\
\text { NPs }\end{array}$ & \begin{tabular}{|lrl} 
E. $\quad$ coli/S. & aureus/B. & cereus/P. \\
aeruginosa & &
\end{tabular} & \begin{tabular}{|l} 
Disc diffusion analysis showed \\
inhibition of $48.14 \%$ (S. aureus), \\
$48.72 \%$ (E. coli), $25.89 \%$ (B. cereus), \\
$11.48 \%$ (P. aeruginosa)
\end{tabular} & 136 \\
\hline $\begin{array}{l}\text { rGO-Ag } \\
\text { NPs }\end{array}$ & E. coli & $100 \%$ inhibition at $20 \mu \mathrm{g} \mathrm{mL}^{-1}$ & 137 \\
\hline $\begin{array}{l}\mathrm{rGO}-\mathrm{Ag} \\
\mathrm{NPs}\end{array}$ & E. coli & $\begin{array}{l}100 \% \text { inhibition of bacterial colony } \\
\text { growth }\end{array}$ & 138 \\
\hline $\begin{array}{l}\mathrm{rGO}-\mathrm{Ag} \\
\mathrm{NPs}\end{array}$ & E. coli/S. aureus & $\begin{array}{l}100 \% \text { inhibition at }[\mathrm{rGO}-\mathrm{Ag} \mathrm{NPs}]= \\
2.5 \times 10^{3} \mu \mathrm{g} \mathrm{mL}^{-1} \text { in } 30 \mathrm{~min}\end{array}$ & 139 \\
\hline $\begin{array}{l}\text { GO- } \mathrm{C}_{2}-\mathrm{Ag} \\
\text { NPs }\end{array}$ & \begin{tabular}{|lr}
$\begin{array}{l}\text { E. coli/S. } \\
\text { aeruginosa/B. } \\
\text { epidermidis/S. aureus }\end{array}$ & subtilis/S. \\
\end{tabular} & $\begin{array}{l}\mathrm{GO}-\mathrm{C}_{2}-\mathrm{Ag} \quad \text { showed } \\
\text { antibacterial activity than } \mathrm{GO}-\mathrm{C}_{0}-\mathrm{Ag} \\
\text { and } \mathrm{GO}-\mathrm{C}_{4}-\mathrm{Ag} \text { due to nearly eight }\end{array}$ & 140 \\
\hline
\end{tabular}

DOI: $10.1039 /$ C6TB01647B - Journal: Journal of Materials Chemistry B: Materials for biology and medicine - Post-print 


\begin{tabular}{|c|c|c|c|}
\hline & & $\begin{array}{l}\text { times higher reactive oxygen species } \\
\text { (ROS), MIC }=\left[0.6-0.8 \mu \mathrm{g} \mathrm{mL}^{-1}\right] \text { (E. } \\
\text { coli and S. epidermidis); MIC }=[2.3- \\
1.6 \mu \mathrm{g} \mathrm{mL}-1](\mathrm{S} . \text { typhimurium and P. } \\
\text { aeruginosa); MIC }=\left[2.3-3.2 \mu \mathrm{g} \mathrm{mL}^{-1}\right] \\
\text { (B. subtilis); MIC }=\left[4.6-3.2 \mu \mathrm{gL}^{-1}\right] \\
\text { (S. aureus) }\end{array}$ & \\
\hline $\begin{array}{l}\text { pG-Ag } \\
\text { NWs }\end{array}$ & E. coli/S. aureus/Candida albicans & $\mid \begin{array}{l}\text { Antimicrobial efficiency } \sim 100 \% \text { by } \\
\text { water electrolysis by using the } \\
\text { conductive graphene/Ag NW coating } \\
\text { as a cathode }\end{array}$ & 141 \\
\hline $\begin{array}{l}\text { GO-Ag } \\
\text { NWs }\end{array}$ & E. coli/S. aureus & $\mathrm{MIC}=16 / 20 \mu \mathrm{g} \mathrm{mL}^{-1}$ & 142 \\
\hline $\begin{array}{l}\mathrm{rGO}-\mathrm{Ag} \\
\text { NPs } \\
\text { hydrogel }\end{array}$ & E. coli & $\begin{array}{l}>97 \% \text { bacterial inactivation for }[\mathrm{E} . \\
\text { coli] }=10^{3}-10^{5} \mathrm{cfu} \text { per } \mathrm{mL}\end{array}$ & 143 \\
\hline $\begin{array}{l}\text { GO- } \\
\text { PLDA- } \\
\text { chitosan- } \\
\text { Au NPs } \\
\end{array}$ & E. coli/S. aureus/P. aeruginosa & $\begin{array}{l}98 \% \text { inactivation for } \mathrm{E} \text {. coli and } \mathrm{P} . \\
\text { aeruginosa, } 79.4 \% \text { for } \mathrm{S} \text {. aureus }\end{array}$ & 128 \\
\hline \begin{tabular}{|l} 
GO- \\
PNVP-Ag \\
NPs
\end{tabular} & E. coli/S. aureus & $\mathrm{MIC}=0.17 / 21.92 \mu \mathrm{g} \mathrm{mL}^{-1}$ & 144 \\
\hline \begin{tabular}{|l|}
$\mathrm{GO} / \mathrm{PA} / \mathrm{Ag}$ \\
$\mathrm{NPs}$ \\
\end{tabular} & E. coli & $\begin{array}{l}98 \% \text { inhibition at }[\mathrm{GO} / \mathrm{PA} / \mathrm{Ag} \mathrm{NPS}]= \\
10^{3} \mu \mathrm{g} \mathrm{mL}^{-1}\end{array}$ & 145 \\
\hline $\begin{array}{l}\text { rGO-PES- } \\
\text { Ag NPs }\end{array}$ & E. coli/S. aureus/P. aeruginosa & Agar diffusion & 126 \\
\hline \begin{tabular}{|l|} 
GO- \\
chitosan- \\
Ag NPs \\
\end{tabular} & & $\mathrm{MIC}=1.09 \mu \mathrm{g} \mathrm{mL}^{-1}$ & 146 \\
\hline $\begin{array}{l}\text { GO-PEG- } \\
\text { Ag NPs }\end{array}$ & E. coli/S. aureus & 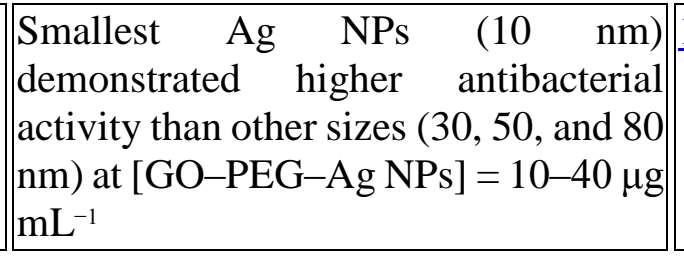 & 147 \\
\hline \begin{tabular}{|l||} 
rGO- \\
MWCNTs- \\
Ag NPs \\
\end{tabular} & E. coli/Bacillus subtilis & $\mathrm{MIC}=15 \mu \mathrm{g} \mathrm{mL}-1$ & 148 \\
\hline \begin{tabular}{l|} 
rGO-Ag in \\
PE/PEO \\
membranes
\end{tabular} & E. coli & $\begin{array}{l}\text { Water purification of [E. coli] }=3 \times 10^{8} \\
\text { cfu per } \mathrm{mL} \text { to }\left[\mathrm{E} \text {. coli] }=7.5 \times 10^{7} \mathrm{cfu}\right. \\
\text { per } \mathrm{mL}\end{array}$ & $\underline{149}$ \\
\hline \begin{tabular}{|l|} 
rGO- \\
HNTs-Ag \\
NPs
\end{tabular} & E. coli/S. aureus & $\mathrm{MIC}=2 \mu \mathrm{g} \mathrm{mL} \mathrm{L}^{-1}$ & $\underline{150}$ \\
\hline
\end{tabular}

DOI: 10.1039/C6TB01647B - Journal: Journal of Materials Chemistry B: Materials for biology and medicine - Post-print 


\begin{tabular}{|c|c|c|c|}
\hline \multicolumn{4}{|c|}{ Gold nanostructures } \\
\hline $\begin{array}{l}\text { rGO-Au } \\
\text { NPs }\end{array}$ & \begin{tabular}{|l} 
E. coli/S. \\
aeruginosa/Bacillus subtilis
\end{tabular} & $\begin{array}{l}97-100 \% \text { killing of } 10^{8} \text { cfu per } \mathrm{mL} \\
\text { pathogens }\end{array}$ & 151 \\
\hline $\begin{array}{l}\text { rGO } \\
\text { wrapped } \\
\text { Au NRs }\end{array}$ & E. coli (UTI 89) & $\begin{array}{l}\text { Photothermal killing of } 5 \times \log \text { cfu per } \\
\mathrm{mL}\end{array}$ & $\underline{152}$ \\
\hline $\begin{array}{l}\text { rGO-Au } \\
\text { NPs }\end{array}$ & $\begin{array}{ll}\mathrm{P} . & \text { aeruginosa/Klebsiella } \\
\text { pneumoniae/S. aureus/B. cereus }\end{array}$ & 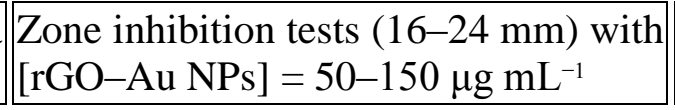 & 153 \\
\hline \multicolumn{4}{|c|}{ Copper nanostructures } \\
\hline $\begin{array}{l}\text { rGO-PLL- } \\
\mathrm{Cu} \text { NPs }\end{array}$ & E. coli/S. aureus & $\begin{array}{l}99 \% \text { killing rate at } 16.3 \mathrm{mg} \mathrm{L}^{-1} \mathrm{Cu} \mathrm{NPs} \\
\text { present on the matrix }\end{array}$ & 154 \\
\hline \multicolumn{4}{|c|}{ Titanium oxide nanoparticles } \\
\hline $\mathrm{rGO}-\mathrm{TiO}_{2}$ & E. coli & $\begin{array}{l}\text { Solar light irradiation of } 2 \mathrm{~h} \text { for killing } \\
5 \times \log \text { cfu per } \mathrm{mL}\end{array}$ & 155 \\
\hline $\begin{array}{l}\mathrm{GO}-\mathrm{TiO}_{2} \\
\text { loaded } \\
\text { cotton }\end{array}$ & E. coli/S. aureus/C. albicans & $\begin{array}{l}\text { 100\% pathogen killing with cotton } \\
\text { loaded with }\left[\mathrm{GO}-\mathrm{TiO}_{2}\right]=0.5 \% \mathrm{GO} / 1.2 \\
\mathrm{~mL} \mathrm{TiCl}_{3}\end{array}$ & $\underline{156}$ \\
\hline $\begin{array}{ll}\mathrm{rGO}- \\
\text { titanate }\end{array}$ & E. coli O157:H7 & $\begin{array}{l}100 \% \text { sterilization in } 15 \mathrm{~min} \text { for free } \\
\text { standing films }\end{array}$ & 157 \\
\hline $\begin{array}{l}\mathrm{rGO}-\mathrm{Ag}- \\
\mathrm{TiO}_{2}\end{array}$ & E. coli & $\begin{array}{l}67 \% \text { inhibition using }\left[\mathrm{rGO}-\mathrm{Ag}-\mathrm{TiO}_{2}\right] \\
=10^{2} \mu \mathrm{g} \mathrm{mL}-1\end{array}$ & $\underline{158}$ \\
\hline \begin{tabular}{|l|}
$\mathrm{GOO}-$ \\
magnetic- \\
$\mathrm{TiO}_{2}$ \\
\end{tabular} & E. coli & $99 \%$ inhibition & $\underline{159}$ \\
\hline $\begin{array}{l}\mathrm{pG}-\mathrm{Au}- \\
\mathrm{TiO}_{2}\end{array}$ & $\begin{array}{l}\text { E. coli/Candida/Rhodopseudanonas } \\
\text { palustris }\end{array}$ & $\begin{array}{l}90-100 \% \text { inactivation using }[\mathrm{pG}-\mathrm{Au}- \\
\left.\mathrm{TiO}_{2}\right]=150 \mu \mathrm{g} \mathrm{mL}\end{array}$ & 160 \\
\hline \multicolumn{4}{|c|}{ Zinc oxide nanostructures } \\
\hline GO-ZnO & E. coli & $\begin{array}{l}\text { Growth reduction at }[\mathrm{GO}-\mathrm{ZnO}]=10 \\
\mu \mathrm{g} \mathrm{mL} L^{-1}\end{array}$ & 161 \\
\hline $\mathrm{GO}-\mathrm{ZnO}$ & $\begin{array}{l}\text { E. coli/B. subtilis/Salmonella } \\
\text { typhimurium/Enterococcus faecalis }\end{array}$ & $\mathrm{MIC}=6.25-25 \mu \mathrm{g} \mathrm{mL}^{-1}$ & 162 \\
\hline $\mathrm{pG}-\mathrm{ZnO}$ & E. coli & 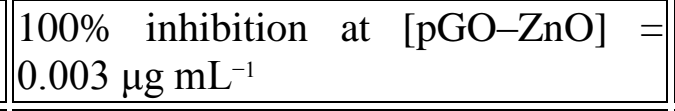 & 163 \\
\hline $\begin{array}{l}\text { GO-ZnO } \\
\text { NWs } \\
\end{array}$ & E. coli & $\begin{array}{l}\text { 95-99.5\% inhibition at [GO-ZnO } \\
\text { NWs] }=10^{3} \mu \mathrm{g} \mathrm{mL}^{-1}\end{array}$ & 164 \\
\hline $\begin{array}{l}\mathrm{GO}-\mathrm{Cu}- \\
\mathrm{ZnO}\end{array}$ & E. coli/S. aureus & Disc diffusion method & $\underline{165}$ \\
\hline
\end{tabular}

DOI: 10.1039/C6TB01647B - Journal: Journal of Materials Chemistry B: Materials for biology and medicine - Post-print 


\begin{tabular}{|c|c|c|c|}
\hline $\begin{array}{l}\mathrm{GO}- \\
\text { chitosan- } \\
\mathrm{ZnO}\end{array}$ & E. coli/S. aureus & $\mathrm{MIC}=62.5-5 \mu \mathrm{g} \mathrm{mL}^{-1}$ & $\underline{166}$ \\
\hline \multicolumn{4}{|c|}{ Iron oxide nanostructures } \\
\hline $\mathrm{GO}-\mathrm{Fe}_{2} \mathrm{O}_{3}$ & E. coli & $\mid \begin{array}{l}91.5 \% \text { inhibition at }\left[\mathrm{GO}-\mathrm{Fe}_{2} \mathrm{O}_{3}\right]=10^{2} \\
\mu \mathrm{g} \mathrm{mL} \mathrm{mL}^{-1}\end{array}$ & 167 \\
\hline $\mathrm{GO}-\mathrm{Fe}_{2} \mathrm{O}_{3}$ & E. coli & \begin{tabular}{|l}
$97 \%$ viability loss at $\left[\mathrm{GO}-\mathrm{Fe}_{2} \mathrm{O}_{3}\right]=100$ \\
$\mu \mathrm{g} \mathrm{mL}-1$
\end{tabular} & 168 \\
\hline $\mathrm{rGO}-\mathrm{Fe}_{2} \mathrm{O}_{3}$ & \begin{tabular}{|l} 
E. coli/S. aureus/Salmonella/E. \\
faecium/E. faecalis/Shigella
\end{tabular} & $93.09 \%$ removal & 169 \\
\hline $\begin{array}{l}\mathrm{GO}- \\
\mathrm{MnFe}_{2} \mathrm{O}_{4} \\
\end{array}$ & E. coli & $\begin{array}{l}82 \% \text { inhibition at }\left[\mathrm{GO}-\mathrm{MnFe}_{2} \mathrm{O}_{4}\right]=10^{2} \\
\mu \mathrm{g} \mathrm{mL}\end{array}$ & 170 \\
\hline $\begin{array}{l}\mathrm{rGO}-\mathrm{GA}- \\
\mathrm{Fe}_{2} \mathrm{O}_{3}\end{array}$ & E. coli/S. aureus & $\begin{array}{l}99.9 \% \text { photothermal killing upon NIR } \\
\text { irradiation for } 10 \mathrm{~min}\end{array}$ & 171 \\
\hline $\begin{array}{l}\mathrm{GO}-\mathrm{Ag} \\
\mathrm{NPs}-\mathrm{Fe}_{2} \mathrm{O}_{3} \\
\end{array}$ & E. coli/S. aureus & $\mathrm{MIC}=25-50 \mu \mathrm{g} \mathrm{mL}^{-1}$ & 172 \\
\hline $\begin{array}{|ll|}\text { rGO-PEI- } \\
\mathrm{Ag} & \mathrm{NPs}- \\
\mathrm{Fe}_{2} \mathrm{O}_{3} & \\
\end{array}$ & E. coli O157:H7 & $\mid \begin{array}{l}99.9 \% \text { photothermal killing using } 0.1 \\
\mu \mathrm{g} \mathrm{mL} \mathrm{mL}^{-1} \text {, laser irradiation for } 10 \mathrm{~min}\end{array}$ & 173 \\
\hline $\begin{array}{l}\mathrm{rGO}-\mathrm{Ag}- \\
\mathrm{CoFe}_{2} \mathrm{O}_{4} \\
\end{array}$ & E. coli/S. aureus & $\begin{array}{l}\text { 97-99\% viability loss using [rGO-Ag- } \\
\left.\mathrm{CoFe}_{2} \mathrm{O}_{4}\right]=12.2 \mu \mathrm{g} \mathrm{mL}^{-1}\end{array}$ & 174 \\
\hline \multicolumn{4}{|c|}{ CuS nanostructures } \\
\hline GO-CuS & E. coli/B. subtilis & $\begin{array}{l}80-100 \% \text { inactivation in a time } \\
\text { dependent manner }(30-60 \mathrm{~min})\end{array}$ & 175 \\
\hline
\end{tabular}

Au NWs: gold nanowires; Au NRs: gold nanorods; GA: glutaraldehyde; GO: graphene oxide; rGO: reduced graphene oxide; pG: pristine graphene; HNTS = Halloysite nanotubes;

MWCNTs: multiwalled carbon nanotubes; PA: polyamide; PE: polyethylene; PES:

polyethersulfone; PEO: polyethylene oxide; PLGA: poly(lactide-co-glycolide); PLL: poly(Llysine); PNVP: poly(N-vinyl pyrrolidone).

\subsubsection{Graphene/silver nanoparticles.}

Throughout the past decades, Ag-based nanomaterials have occupied an important position as antimicrobial agents and have been integrated into several commercial products (see Fig. 1 for some examples). One of the key characteristics of silver nanoparticles (Ag NPs) is that at low concentrations they are toxic to microbes, but are safe for human cells. There are however challenges associated with the oxidation and aggregation of Ag NPs, which compromise their antimicrobial properties and thus limit their efficient use. By attaching Ag NPs to graphenebased materials, stable antibacterial matrices are obtained. Gao et al. demonstrated that the presence of GO not only slows down $\mathrm{Ag}$ NPs oxidation, but also enables $\mathrm{Ag}^{+}$ion recrystallization on the GO surface. ${ }^{176} \mathrm{~A}$ large number of $\mathrm{Ag}$ containing composite materials 22

DOI: $10.1039 /$ C6TB01647B - Journal: Journal of Materials Chemistry B: Materials for biology and medicine - Post-print 
for antibacterial applications, where the materials have been used as substrates and templates for binding Ag NPs, have been proposed with graphene materials being one of them. By growing Ag NPs on the surface of GO, several groups using different approaches have synthesized GO-Ag NP and $\mathrm{rGO}-\mathrm{Ag} \mathrm{NP}$ nanocomposites with significantly improved antibacterial activities when compared to GO and Ag NPs taken separately. ${ }^{123-}$ 125,128,131,134,137,147,172,177-187 The enhanced antimicrobial activity of GO-Ag NP nanocomposites is attributed to the presence of Ag NPs. Additionally, the high concentration of oxygenated groups confers on GO-Ag NPs sheets the versatility to bind to solid surfaces via covalent and non-covalent interactions, thus providing multiple opportunities to develop multifunctional materials with antimicrobial activity. However, despite these independent demonstrations of the strong antibacterial ability of $\mathrm{GO}-\mathrm{Ag}$ nanomaterials, the demonstration of the real advantage of GO-Ag as a new generation of antibacterial agents over Ag NPs was highlighted by Peng and co-workers only in 2013. ${ }^{179}$ GO-Ag nanocomposites with different Ag NPs/GO ratios were synthesized and their antibacterial activities were assessed against Gram-negative and Gram-positive bacteria. Compared to Ag NPs, GO/Ag NPs with an optimal ratio of Ag NPs/GO are much more efficient and show synergistically enhanced, strong antibacterial activities at doses as low as $2.5 \mu \mathrm{g} \mathrm{mL}{ }^{-1}$. While GO/Ag NPs function as a bactericide against Gram-negative E. coli through bacterial cell disruption, bacteriostatic effects by inhibiting cell division are the underlying mechanism for Gram-positive S. aureus (Fig. 9A) ${ }^{179}$

(A)

(a)

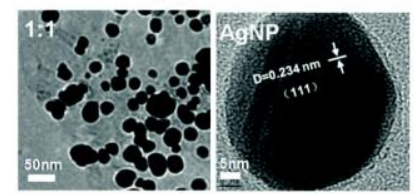

(c)

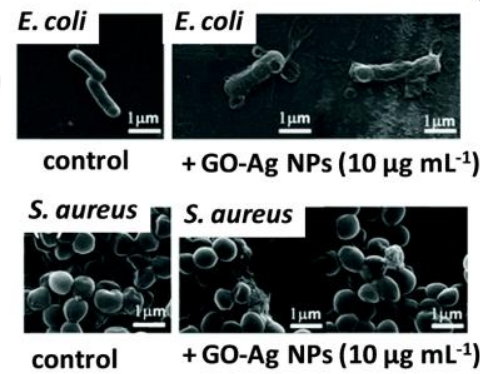

(b)

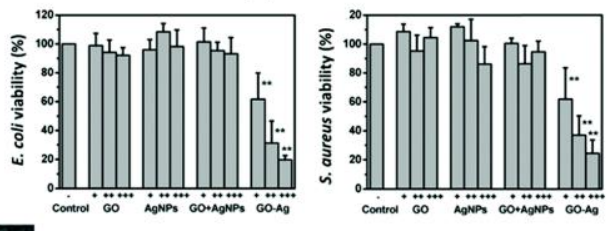

(B)

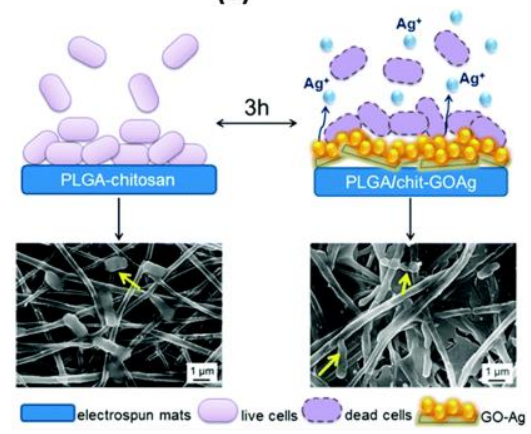

Fig. 9 (A) (a) TEM images of GO/Ag NPs, (b) bacterial cell viability of E. coli and S. aureus after treatment with either pure GO sheets, pure Ag NPs or GO-Ag NP (1/1) nanocomposites, (c) SEM images of E. coli and S. aureus cells without and with GO-Ag NP treatment at $10 \mu \mathrm{g}$ $\mathrm{mL}^{-1}$ for $2.5 \mathrm{~h}$ (reprint with permission from ref. 179); (B) SEM image of a surface of PLGAchitosan mats and PLGA-chitosan-GO/Ag NPs and morphological changes of E. coli (reprint with permission from ref. 128).

Focusing on the work of the last few months, some interesting works can be cited. $\frac{128,142,147,183,184}{1}$ Antimicrobial electrospun mats, synthesized through a post-fabrication binding of graphenebased nanocomposites to the nanofibers' surface, were demonstrated by Elimelech and coworkers (Fig. 9B). ${ }^{128}$ Poly(lactide-co-glycolide) (PLGA) and chitosan were electrospun to yield 23

DOI: 10.1039/C6TB01647B - Journal: Journal of Materials Chemistry B: Materials for biology and medicine - Post-print 
cylindrical polymer fibers, and were further functionalized with GO/Ag NPs via chemical reaction between the carboxyl groups of GO and the primary amine groups of the PLGAchitosan fibers. Upon direct contact with bacterial cells, Gram-negative and Gram-positive bacteria were effectively inactivated. ${ }^{128}$ From the SEM images (Fig. 9B) of PLGA-chitosan and PLGA-chitosan-GO/Ag NP mats, E. coli lost their morphological integrity upon contact with the GO/Ag NP nanocomposites. E. coli, P. aeruginosa and S. aureus became flattened and wrinkled after their contact with PLGA-chitosan-GO/Ag NPs. The deposition of Ag nanowires onto GO was recently proposed as an alternative antibacterial material where bacterial death is due to damage of the cell membrane integrity, and DNA, RNA and protein leakage due to oxidative damage of the bacteria through the release of reactive oxygen species brought by the release of silver ions.1ㅡㄴ GO@PEG@Ag NPs, developed using polyoxyethylene bis(amine) (PEG) directed Ag NP growth on GO, were reported by Liu and co-workers with an antibacterial activity exceeding that of Ag NPs alone. A matrix of GO@PEG@Ag NPs with 10 $\mathrm{nm}$ particle size of Ag NPs showed the highest antibacterial activity when compared to other sizes $(30,50,80 \mathrm{~nm}) . \underline{147}$ GO loaded cellulose membranes modified with Ag NPs formed in situ significantly lowered the release of $\mathrm{Ag}$ ions and exhibited strong antibacterial activity against S. aureus and E. coli. $\frac{184}{}$

\subsubsection{Graphene/gold nanoparticles.}

The integration of gold nanostructures onto graphene-based materials has in addition been considered. $\frac{151,152,188,189}{1}$ Das and co-workers showed that rGO nanosheets decorated with gold nanoparticles (Au NPs) possess high antibacterial activity; bacterial cell death is caused by the leakage of sugars and proteins from the cell membrane once in contact with the rGO-Au NPs material. $\underline{151}$

More recently, graphene wrapped Au nanostructures were used for the photothermal ablation of bacteria. $\frac{152,188}{2}$ Our group developed Au NRs coated with rGO-PEG (rGO-PEG-Au NRs) for the selective killing of uropathogenic E. coli UTI89 (Fig. 10). More importantly, targeted killing of E. coli UTI89 was achieved through functionalization of the photothermal agent with multimeric heptyl $\alpha$-D-mannoside probes. This currently offers a unique biocompatible method for the ablation of pathogens with the opening of probably a new possibility for clinical treatments of patients with urinary infections.

DOI: 10.1039/C6TB01647B - Journal: Journal of Materials Chemistry B: Materials for biology and medicine - Post-print 


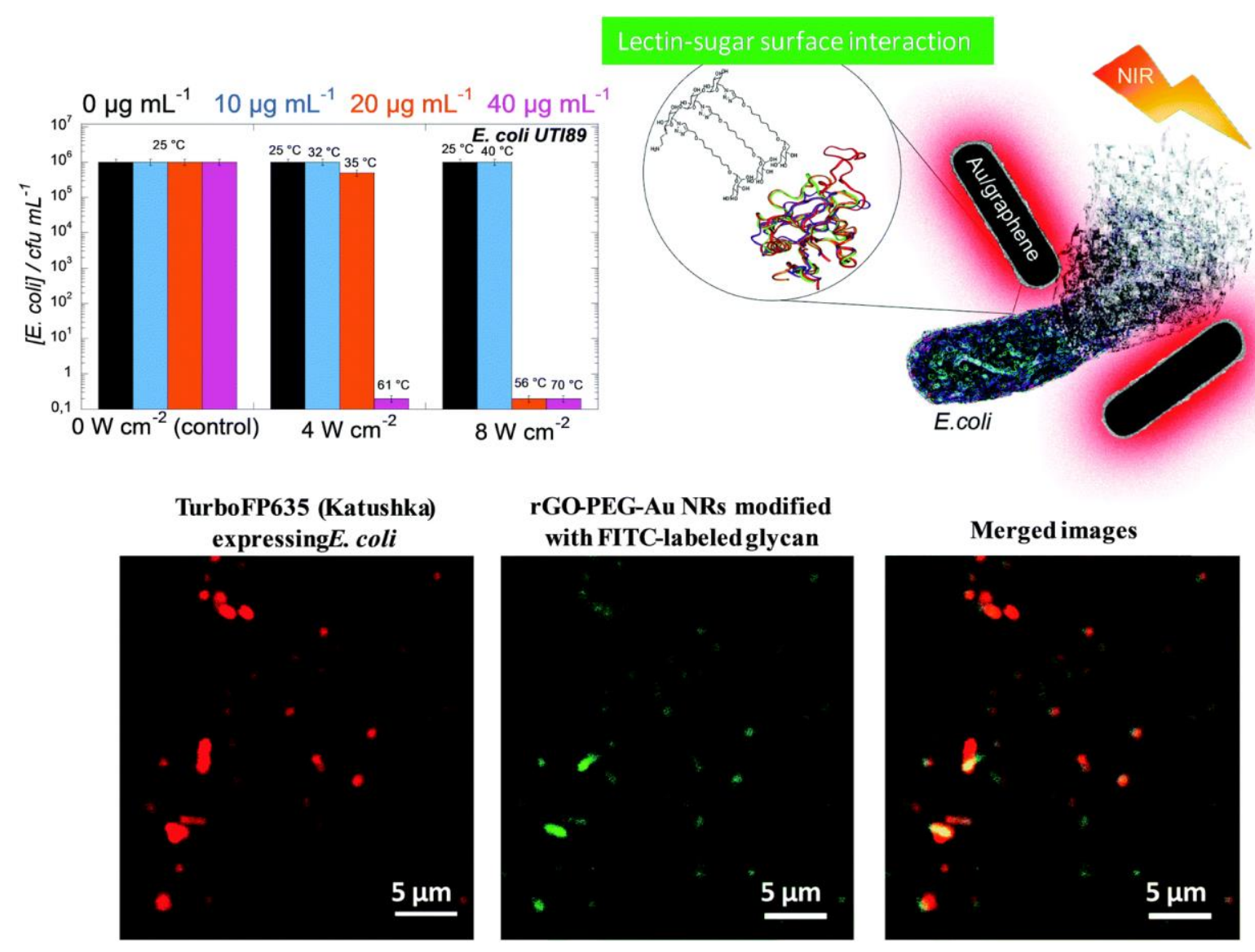

Fig. 10 E. coli UTI89 viability in the presence of multimeric heptyl- $\alpha$-D-mannoside modified rGO-PEG-Au NR particles upon irradiation at 4 or $8 \mathrm{~W} \mathrm{~cm}^{-2}$ for $10 \mathrm{~min}$ at $700 \mathrm{~nm}$ together with effective targeting demonstration. The fluorescence images correspond to E. coli UTI89 expressing the fluorescent Katushka protein, to FTIC-labeled multimeric heptyl- $\alpha$-Dmannoside modified rGO-PEG-Au NRs and the overlap of both images (reprint with permission from ref. 152).

\subsubsection{Graphene/copper nanoparticles.}

Several reports indicated that copper nanoparticles ( $\mathrm{Cu}$ NPs) at high concentrations are toxic to most microorganisms as the redox properties of $\mathrm{Cu}$ NPs cause cellular damage such as the oxidation of proteins and lipids. It has thus become important to control the release of $\mathrm{Cu}^{2+}$ from $\mathrm{Cu}$ NPs. To address this issue, $\mathrm{Cu}$ NPs were integrated onto poly-L-lysine modified rGO. ${ }^{154}$ This hybrid proved to be highly stable over a long time, and showed excellent water solubility as well as antibacterial activity.

\subsubsection{Graphene/titanium oxide nanoparticles.}

While Au NPs allow ablation of pathogens using the photothermal effects, photocatalytic inactivation under solar irradiation can be achieved using titanium oxide nanoparticles $\left(\mathrm{TiO}_{2}\right.$ NPs) as a promising alternative for the removal of pathogens from water (Table 2). $\frac{155-157,159}{}$ Upon excitation of $\mathrm{TiO}_{2}$ by light, the photon energy generates electron-hole pairs on the $\mathrm{TiO}_{2}$ surface, which can react with oxygen and water molecules to form hydroxyl radicals,

DOI: 10.1039/C6TB01647B - Journal: Journal of Materials Chemistry B: Materials for biology and medicine - Post-print 
responsible for the disinfection of bacteria. 190 Akhavan and Ghaderi proposed photoinactivation of bacteria by solar light irradiation using $\mathrm{rGO} / \mathrm{TiO}_{2}$ thin films already in 2009. 155 The use of $\mathrm{GO}-\mathrm{TiO}_{2}$ nanocomposites on cotton to reduce bacteria and fungi was proposed more recently by Karimi et al. ${ }^{156}$ Furthermore, the antibacterial properties of $\mathrm{GO}-\mathrm{TiO}_{2}$ modified with magnetic particles were recently investigated and excellent antimicrobial properties were obtained..$\frac{159}{}$ After 30 min solar irradiation, the bacterial inactivation rates nearly reached $100 \%$. The low cost of $\mathrm{GO}$ and $\mathrm{TiO}_{2}$ and the simplicity of manufacturing magnetic $\mathrm{GO}-\mathrm{TiO}_{2}$ make it a promising candidate for water disinfection treatment.

\subsubsection{Graphene/zinc oxide nanoparticles.}

Like Ag NPs, zinc oxide nanoparticles (ZnO NPs) have been widely used as antibacterial agents. As they can be prepared easily and cost effectively they are of particular interest. The release of zinc ions from $\mathrm{ZnO}$ was suggested as one of the primary antibacterial mechanisms of $\mathrm{ZnO}$ NPs. Moreover, the penetration and disorganization of the bacterial membrane upon contact with $\mathrm{ZnO}$ NPs is believed to contribute in addition to their antibacterial ability. However, as with all nanoparticles, aggregation interferes with their long lasting antibacterial character. Some groups thus looked at the integration of $\mathrm{ZnO}$ NPs onto graphene nanomaterials. $\frac{161-163,165,166}{}$ Wang et al. prepared GO-ZnO NPs by a facile one-pot reaction where the $4 \mathrm{~nm}$ sized ZnO NPs are homogeneously anchored onto the GO sheets. $\frac{161}{}$ GO helped the dispersion of $\mathrm{ZnO} \mathrm{NPs}$, slowed down the dissolution of $\mathrm{ZnO}$, and acted as a storage site for dissolved zinc ions, thus enabling the intimate contact of E. coli with $\mathrm{ZnO}$ NPs and zinc ions. $\frac{161}{}$ A $\mathrm{ZnO}$ decorated chitosan-GO nanocomposite was recently reported by Chowdhuri et al. with enhanced antimicrobial activity due to ROS generation; the nanocomposite exhibited MIC

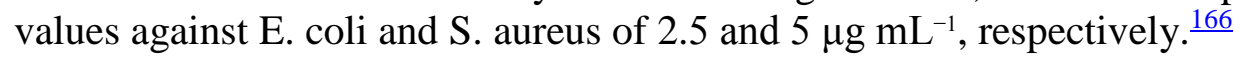

\subsubsection{Graphene/iron oxide particles.}

There is still a critical need to develop new approaches that can clean bacteria from water. Nanomaterials have been proposed for such treatments. However, due to their small size they are difficult to separate from water, which not only results in difficulty in recycling but also in the reuse of the materials. Magnetic nanoparticles, which can be easily separated from any medium with the use of an external magnet, are a promising solution to these problems. The use of magnetic antibacterial graphene nanocomposites to clean pathogens in water has been proposed. $\frac{169-172}{T}$ The successful synthesis of $\mathrm{Fe}_{3} \mathrm{O}_{4}$ modified GO using a solvothermal method was proposed by Shen and co-workers for the efficient (93\%) removal of E. coli, whereas it

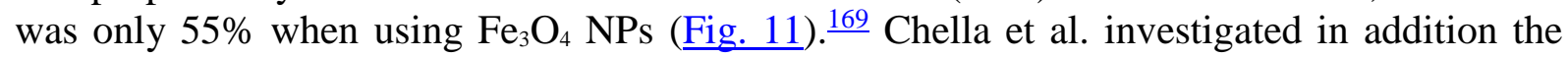
bactericidal activity of magnetic $\mathrm{GO}\left(\mathrm{GO}-\mathrm{MnFe}_{2} \mathrm{O}_{4}\right)$ on E. coli and showed a $82 \%$ loss of viability after $2 \mathrm{~h}$ contact with $100 \mu \mathrm{g} \mathrm{mL} \mathrm{m}^{-1} \mathrm{GO}-\mathrm{MnFe}_{2} \mathrm{O}_{4} \cdot \frac{170}{}$ An antibacterial nanocomposite of GO, $\mathrm{CoFe}_{2} \mathrm{O}_{4}$ and Ag NPs (Ag NPs@GO@ $@ \mathrm{CoFe}_{2} \mathrm{O}_{4}$ ) was developed by Ma et al. for efficient disinfection of water contaminated with E. coli and S. aureus..$^{174}$

DOI: 10.1039/C6TB01647B - Journal: Journal of Materials Chemistry B: Materials for biology and medicine - Post-print 
(A)

(a)
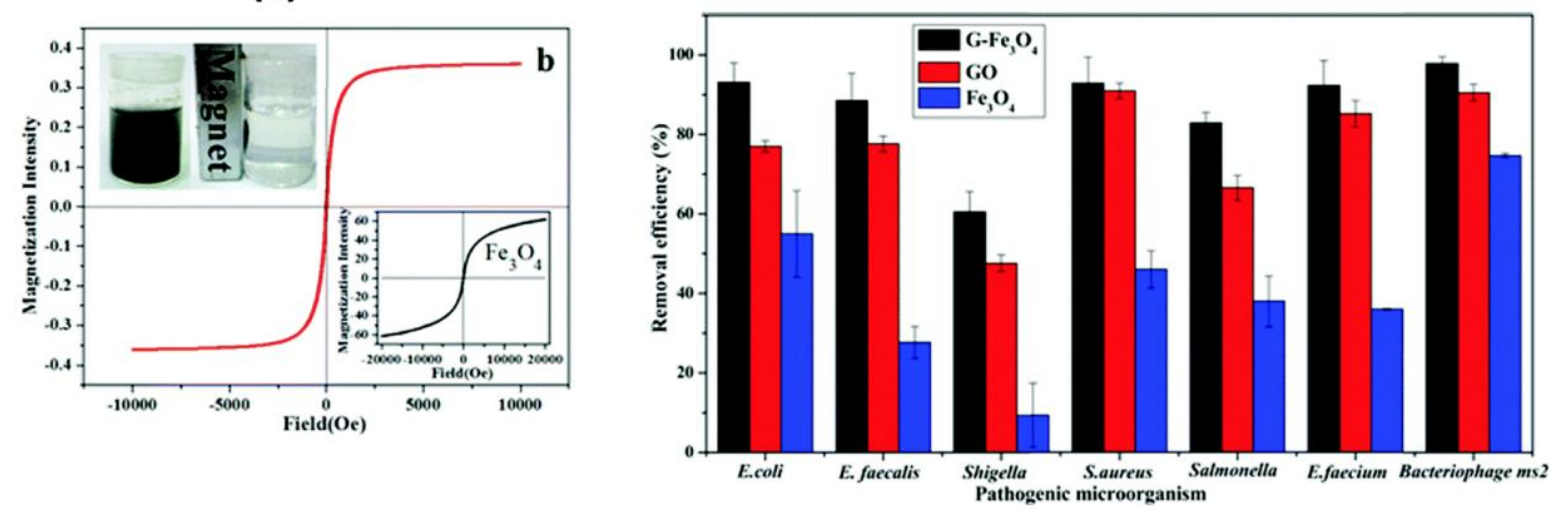

(B)

(a)
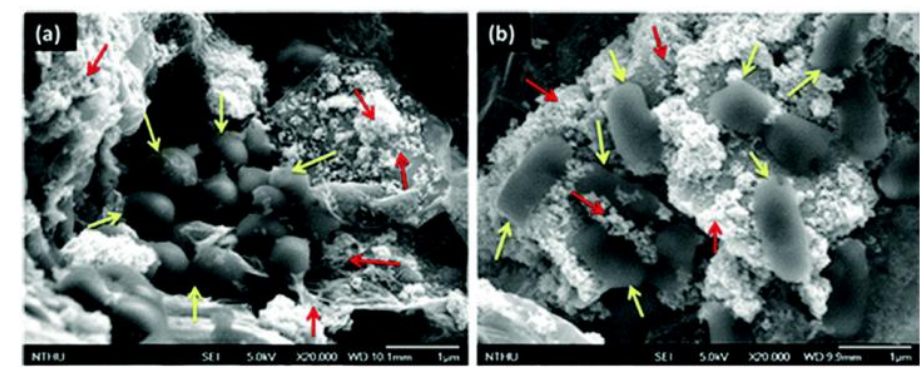

(b)

(b)

Fig. 11 (A) (a) Room temperature magnetization curves of $\mathrm{Fe}_{3} \mathrm{O}_{4}$ and $\mathrm{GO}-\mathrm{Fe}_{3} \mathrm{O}_{4}$, (b) removal of different pathogenic microorganisms using $\mathrm{GO}, \mathrm{Fe}_{3} \mathrm{O}_{4}$ and $\mathrm{GO}-\mathrm{Fe}_{3} \mathrm{O}_{4}$ (reprint with permission from ref. 169); (B) (a) SEM images of magnetic glutaraldehyde modified GO matrices (red arrows) capturing S. aureus and E. coli, (b) photothermal ablation of captured pathogens (reprint with permission from ref. 174).

Different from these reports, $\mathrm{Wu}$ et al. developed a magnetic glutaraldehyde modified GO matrix for harvesting bacteria and used the near-infrared photothermal properties of the graphene matrix for the photothermal killing of the pathogens (Fig. 11B). Indeed, the magnetic properties allowed bacteria to be rapidly trapped in a small volume by an external magnet. The synergistic effects increased the heating efficacy of the matrix upon NIR laser irradiation and resulted in efficient thermal ablation $(99 \%)$ of the captured bacteria. ${ }^{171}$

\subsubsection{Graphene/copper sulfide nanoparticles.}

Another approach was taken by Yu et al., who proposed carboxylated GO/copper sulfide (GO$\mathrm{COOH}-\mathrm{CuS})$ as an antibacterial nanocomposite for the removal of pathogens. ${ }^{175}$ The antibacterial activity was evaluated under solar light irradiation (Fig. 12). While GO-COOH$\mathrm{CuS}$ could inactivate pathogens in the dark to some extent ( $40 \%$ for E. coli, $30 \%$ for B. subtilis), under solar light irradiation, the survival rate decreased drastically. After $60 \mathrm{~min}, 100 \%$ inactivation was achieved. This efficient deactivation is linked to the photocatalytic activity of $\mathrm{GO}-\mathrm{COOH}-\mathrm{CuS}$. Under solar light irradiation, electrons are generated from $\mathrm{CuS}$ NPs and

DOI: 10.1039/C6TB01647B - Journal: Journal of Materials Chemistry B: Materials for biology and medicine - Post-print 
transferred to $\mathrm{GO}-\mathrm{COOH}$, where they react with adsorbed surface oxygen to produce reactive oxygen species, assisting the inactivation process of the pathogens. ${ }^{175}$

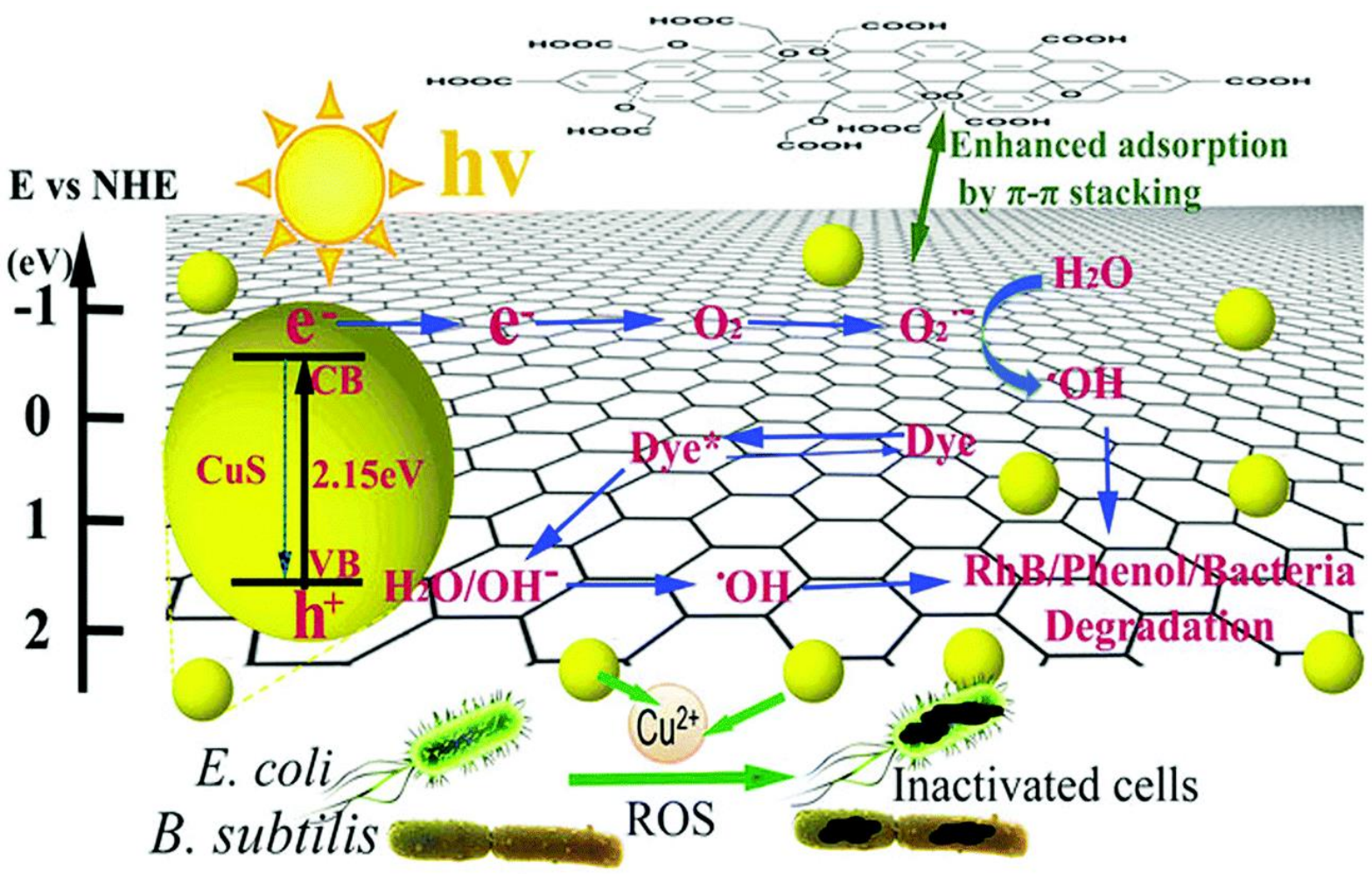

Fig. 12 Schematic illustration of the photocatalytic and antibacterial mechanism of GO$\mathrm{COOH}-\mathrm{CuS}$ (reprint with permission from ref. 175).

\section{Conclusion and perspectives}

A global summary of the bactericidal efficiency and the possibility to interfere with biofilm formation using graphene nanostructures has been provided in this review. The different studies have resulted in the preparation of a large amount of graphene-based scaffolds. Their antimicrobial properties were tested in the majority of cases against E. coli and S. aureus as model pathogens. In light of the increasing spread of antibiotic resistant bacteria associated with their severe threat against public health worldwide, it might be important to investigate other pathogenic species and phenotypes to illustrate the broad range of bactericidal properties of graphene nanostructures. Indeed, most of their action has still to be validated on other bacterial strains. Even though some studies on P. aeruginosa, E. faecalis, B. subtilis and S. typhimurium are emerging, a deeper understanding is still required to conclude about the general antibacterial ability of graphene. These studies might in addition help in giving general guidelines as to how to modulate the graphene nanostructures to obtain desired antimicrobial properties. The antimicrobial mechanism of graphene based nanostructures has indeed been the focus of several recent investigations; a deeper and more consistent understanding of the underlying molecular mechanisms is however still required. The other difficulty associated with graphene based materials is the existence of different parameters influencing their antibacterial properties. Orientation, size, shape, structural defects as well as surface functional groups are different physico-chemical characteristics, all strongly 28

DOI: 10.1039/C6TB01647B - Journal: Journal of Materials Chemistry B: Materials for biology and medicine - Post-print 
influencing the biological response and defining the antibacterial activity of the graphene family. Well-dispersed graphene sheets have been, for example, shown to display stronger antibacterial activity among several graphene-family nanomaterials. Thus the combination with biocompatible polymers and different nanoparticles was a logical way to further improve the biocompatibility and dispersibility of a broad range of graphene based structures. Depending on the application sought after (e.g. wound healing, treatment of urinal infection, disinfection of water, etc.), different scaffolds are now available and their application and commercialization should be the main focus over the next years. One major limitation for these advancements is that, currently, nonsystematic in vivo antibacterial activity has been demonstrated in animal models. While graphene based materials may be beneficial for wound healing and dental care, future applications in vivo should be not ruled out. One important question that has to be answered first is whether graphene nanomaterials can selectively target pathogenic microorganisms without affecting normal mammalian cells or non-pathogenic bacteria? Only a few studies associated with the selective killing of pathogenic microorganisms over non-pathogenic ones are provided. One notably uses sugar modified graphene coated gold nanorods for the selective accumulation of E. coli UTI89 close to the nanostructures, allowing the use of lower light power to eradicate the pathogenic microorganism in a photothermal ablation approach. $\frac{152}{}$

While the bridge to the biomedical market is still missing, material scientists have not slowed down in proposing different graphene based materials as antibacterial agents. Chen and coworkers reported for example recently the use of Pluronic F-127, a biocompatible block polymer, modified GO, together with water shock treatment (e.g. a sudden decrease in environmental salinity) as a novel antibacterial strategy. $\underline{102}$

Several works on the antibacterial properties of graphene quantum dots (G-QDs), graphene nanosheets of $<20 \mathrm{~nm}$ in lateral dimensions, have been highlighted. $\frac{83,191,192}{}$ Unlike their C-dot cousins, G-QDs have been found to have lower toxicity than GO and cause no apparent toxicity in vivo. $\frac{193}{}$ These results are a step further to the missing in vivo studies as evoked above. Further G-QD suspensions are able to generate reactive oxygen species (ROS) upon photo-excitation, allowing such nanostructures to be used for the photodynamic treatment of pathogens, an approach only marginally developed currently for graphene-based nanostructures.

\section{Acknowledgements}

Financial support from the Centre National de la Recherche Scientifique (CNRS), the University Lille 1, the Hauts-de-France region, the Institut Universitaire de France (IUF), the Agence National de la Recherche (ANR), the CPER Photonics for Society, and the EU through the Marie Sklodowska-Curie action (H2O2-MSCA-RISE-2015, PANG-690836) is acknowledged.

\section{References}

1. J. O'Neill, Tackling Drug-resistance infections globally: Final Report and Recommondations2016,http://amrreview.org/sites/default/files/160525_Final\%20paper_with\%20cover.pdf.

2. B. S. Atiyeh, S. A. Dibo and S. N. Hayek, Int. Wound J., 2009, 6, 420-430.

DOI: 10.1039/C6TB01647B - Journal: Journal of Materials Chemistry B: Materials for biology and medicine - Post-print 
3. M. F. Erdoğan, F. A. Tatar, U. Unlütürk, N. Cin and A. R. Uysal, Thyroid, 2013, 23, 342-345.

4. S. Silver, FEMS Microbiol. Rev., 2003, 27, 341-353.

5. R. G. Sibbald, D. Williamson, H. Orsted, K. Campbell, D. Keast, D. Krasner and D. Sibbald, Ostomy Wound Manage., 2000, 46, 14-22.

6. X. Zhu, A. F. Radovic-Moreno, J. Wu, R. Langer and J. Shi, Nano Today, 2014, 9, 478498.

7. R. Y. Pelgrift and A. J. Friedman, Adv. Drug Delivery Rev., 2013, 65, 1803-1815.

8. A. J. Huh and Y. J. Kwon, J. Controlled Release, 2011, 156, 128-145.

9. K. Forier, K. Raemdonck, S. C. De Smedt, J. Demeester, T. Coenye and K. Braeckmans, J. Controlled Release, 2014, 190, 607-623.

10. G. Franci, A. Falanga, S. Galdiero, L. Palomba, M. Rai, G. Morelli and M. Galdiero, Molecules, 2015, 20, 8856-8874.

11. H. Jinseok and S. Z. Hua, Sensors, 2009, 9, 4483-4502.

12. Y. Chen, Y. Xianyu, X. Wang, Y. Wang, X. Zhang, R. Cha, J. Sun and X. Jiang, ACS Nano, 2015, 9, 3184-3191.

13. S. Liu, T. H. Zeng, M. Hofmann, E. Burcombe, J. Wei, R. Jiang, J. Kong and Y. Chen, ACS Nano, 2011, 5, 6971-6980.

14. A. Barras, F. A. Martin, O. Bande, J. S. Baumann, J.-M. Ghigo, R. Boukherroub, C. Beloin, A. Siriwardena and S. Szunerits, Nanoscale, 2013, 5, 2307.

15. M. Khanal, F. Larsonneur, V. Raks, A. Barras, J.-S. Baumann, F. Ariel Martin, R. Boukherroub, J.-M. Ghigo, C. Ortiz Mettet, V. Zaitsev, J. M. Garcia Fernances, C. Beloin, A. Siriwardena and S. Szunerits, Nanoscale, 2015, 7, 2325-2335.

16. M. Khanal, V. Raks, R. Issa, V. Chernyshenko, A. Barras, J. M. Garcia Fernandes, A. Siriwardena, I. Cooper, P. Cragg, L. I. Mikhalovska, V. Zaitsev, R. Boukherroub and S. Szunerits, Part. Part. Syst. Charact., 2015, 32, 822-830.

17. K. K. Y. Wong and X. Liu, MedChemComm, 2010, 1, 125-131.

18. H. Kong and J. Jang, Langmuir, 2008, 24, 2051-2056.

19. C.-C. Huang, C.-T. Chen, Y.-C. Shiang, Z.-H. Lin and H.-T. Chang, Anal. Chem., 2009, 81, 875-882.

20. G. Bülbül, A. Hayat and S. Andreescu, Sensors, 2015, 15, 30736-30758.

21. S. Wang, A. K. Singh, D. Senapati, A. Neely, H. Yu and P. C. Ray, Chem. - Eur. J., 2015, 16, 5600-5606.

22. S. Szunerits, A. Barras and R. Boukherroub, Int. J. Environ. Res. Public Health, 2016, $13,43$.

23. E. Tegou, M. Magana, A. E. Katsogridaki, A. Ioannidis, V. Raptis, S. Jorda, S. Chatzipanagiotou, S. Chatzandroulis, C. Ornelas and G. P. Tegos, Biomaterials, 2016, $89,38-55$.

24. M. Pumera and Y. Miyahara, Nanoscale, 2009, 1, 260-265.

25. S. S. Nanda, G. C. Papaefthymiou and D. K. Yi, Crit. Rev. Solid State Mater. Sci., 2015, 40, 291-315.

26. T. H. D. Nguyen, M. Lin and A. Mustapha, J. Food Prot., 2015, 78, 996-1002.

27. R. Zhou and H. Gao, Wiley Interdiscip. Rev.: Nanomed. Nanobiotechnol., 2014, 6, 452 474.

28. A. M. Pinto, I. C. Goncalves and F. D. Magalhaes, Colloid Surf., B, 2013, 111, 188202.

29. W. S. Hummers and J. R. E. Offerman, J. Am. Chem. Soc., 1958, 80, 1339.

DOI: 10.1039/C6TB01647B - Journal: Journal of Materials Chemistry B: Materials for biology and medicine - Post-print 
30. D. R. Dreyer, S. J. Park, C. W. Bielawski and R. S. Ruoff, Chem. Soc. Rev., 2010, 39, 228.

31. O. Fellahi, M. R. Das, Y. Coffinier, S. Szunerits, T. Hadjersi, M. Maamache and R. Boukherroub, Nanoscale, 2011, 3, 4662.

32. S. Stankovich, D. A. Dikin, R. D. Piner, K. A. Kohlhaas, A. Kleinhammes, Y. Jia, Y. Wu, S. T. Nguyen and R. S. Ruoff, Carbon, 2007, 45, 1558-1565.

33. H. J. Shin, K. K. Kim, A. Benayad, s. M. Yoon, H. K. Park and I. S. Jung, et al. , Adv. Funct. Mater., 2009, 19, 1987.

34. H. Park and R. S. Ruoff, Nat. Nanotechnol., 2009, 4, 217.

35. C. A. Amarnath, C. E. Hong, N. H. Kim, B. C. Ku, T. Kuila and J. H. Lee, Carbon, 2011, 49, 3497.

36. X. Fan, W. Peng, Y. Li, S. Wang, G. Zhang and F. Zhang, Adv. Mater., 2008, 20, 4490.

37. Z. J. Fan, W. Kai, J. Yan, T. Wei, L. J. Zhi and J. Feng, et al. , ACS Nano, 2011, 5, 191.

38. I. K. Moon, J. H. Lee, R. S. Ruoff and H. Lee, Nat. Commun., 2010, 73, 1.

39. D. R. Dreyer, S. Murali, S.-E. Zhu, R. S. Ruoff and R. S. Bielawski, J. Mater. Chem., 2011, 21, 3443.

40. M. J. Allen, V. C. Tung and R. B. Kaner, Chem. Rev., 2010, 110, 132.

41. O. C. Compton, B. Jain, D. A. Dikin, A. Abouimrane, K. Amine and S. T. Nguyen, ACS Nano, 2011, 5, 4380.

42. I. Kaminska, A. Barras, Y. Coffinier, W. Lisowski, J. Niedziolka-Jonsson, P. Woisel, J. Lyskawa, M. Opallo, A. Siriwardena, R. Boukherroub and S. Szunerits, ACS Appl. Mater. Interfaces, 2012, 4, 5386-5393.

43. I. Kaminska, M. R. Das, Y. Coffinier, J. Niedziolka-Jonsson, J. Sobczak, P. Woisel, J. Lyskawa, M. Opallo, R. Boukherroub and S. Szunerits, ACS Appl. Mater. Interfaces, 2012, 4, 1016.

44. I. Kaminska, M. R. Das, Y. Coffinier, J. Niedziolka-Jonsson, P. Woisel, M. Opallo, S. Szunerits and R. Boukherroub, Chem. Commun., 2012, 48, 1221.

45. D. Li, M. B. Muller, S. Gilje, R. B. Kaner and G. G. Wallace, Nat. Nanotechnol., 2008, 3, 101-105.

46. V. C. Tung, M. J. Allen, Y. Yang and R. B. Kaner, Nat. Nanotechnol., 2009, 4, 25.

47. C. Zhu, S. W. Guo, Y. Fang and S. Dong, ACS Nano, 2010, 4, 2429.

48. D. Li, M. B. Mueller, S. Gilje, R. B. Kaner, G. G. Wallace and G. Gordon, Nat. Nanotechnol., 2008, 3, 101-105.

49. M. J. Fernandez-Merino, L. Guardia, J. I. Paredes, S. Villar-Rodil, P. Solis-Fernandez, A. Martinez-Alonso and J. M. D. Tascon, J. Phys. Chem. C, 2010, 114, 6426-6432.

50. J. Gao, F. Liu, Y. L. Liu, N. Ma, Z. Q. Wang and X. Zhang, Chem. Mater., 2010, 22, 2213-2218.

51. C. Z. Zhu, S. J. Guo, Y. X. Fang and S. J. Dong, ACS Nano, 2010, 4, 2429-2437.

52. D. R. Dreyer, S. Murali, Y. Zhu, R. S. Ruoff and C. W. Bielawski, J. Mater. Chem., 2011, 21, 3443-3447.

53. S. F. Pei, J. P. Zhao, J. H. Du, W. C. Ren and H. M. Cheng, Carbon, 2010, 48, 44664474.

54. Z. J. Fan, K. Wang, T. Wei, J. Yan, L. P. Song and B. Shao, Carbon, 2010, 48, 16861689.

55. Z. J. Fan, K. Wang, J. Yan, T. Wei, L. J. Zhi, J. Feng, Y. M. Ren, L. P. Song and F. Wei, ACS Nano, 2011, 5, 191-198.

56. Z. Zhang, H. Chen, C. Xing, M. Guo, F. Xu, X. Wang, H. J. Gruber, B. Zhang and J. Tang, Nano Res., 2011, 4, 599.

DOI: 10.1039/C6TB01647B - Journal: Journal of Materials Chemistry B: Materials for biology and medicine - Post-print 
57. Y. Wang, Z. X. Shi and J. Yin, ACS Appl. Mater. Interfaces, 2011, 3, 1127-1133.

58. F. Yang, Y. Q. Liu, L. A. Gao and J. Sun, J. Phys. Chem. C, 2010, 114, 22085-22091.

59. I. Kamińska, M. R. Das, J. Niedziółka-Jönsson, P. Woisel, J. Lyskawa, M. Opałło, R. Boukherroub and S. Szunerits, ACS Appl. Mater. Interfaces, 2012, 4, 1016-1020.

60. L. Q. Xu, W. J. Yang, K.-G. Neoh, E.-T. Kang and G. D. Fu, Macromolecules, 2010, 43, 8336 .

61. O. C. Compton and S. T. Nguyen, Small, 2010, 6, 711-723.

62. K. C. Marshall, ASM News, 1992, 202-207.

63. O. N. Ruiz, K. A. Shiral Fernando, B. Wang, N. A. Brown, P. G. Luo, N. D. McNamara, M. Vangsness, Y.-P. Sun and C. E. Bunker, ACS Nano, 2011, 5, 8100-8107.

64. T. S. Sreeprasad, M. Shihabudheen Maliyekkal, K. Deepti, K. Chaudhari, P. Lourdu Xavier and T. Pradeep, ACS Appl. Mater. Interfaces, 2011, 3, 2643-2654.

65. S. Some, S.-M. Ho, P. Dua, E. Hwang, Y. Hun Shin, H. Yoo, J.-S. Kang, D.-K. Lee and H. Lee, ACS Nano, 2012, 6, 7151-7161.

66. F. Perreault, A. F. de Faria, S. Nejati and M. Elimelech, ACS Nano, 2015, 9, 72267236.

67. J. He, X. Zhu, Z. Qi, C. Wang, X. Mao, C. Zhu, Z. He, M. Li and Z. Tang, ACS Appl. Mater. Interfaces, 2015, 7, 5605-5611.

68. H. M. Hegab, A. ElMekawy, L. Zou, D. Mulcahy, C. P. Saint and M. Ginic-Markovic, Carbon, 2016, 105, 362-376.

69. E. S. C. Grace, A. Annamalai, G. Ponmari, C. Vani, A. Rose, A. B. Marahatta and V. Gunasekaran, J. Nanosci. Nanotechnol., 2016, 16, 2447-2452.

70. X. Zou, L. Zhang, Z. Wang and L. Yang, J. Am. Chem. Soc., 2016, 138, 2064-2077.

71. S. S. Nanda, D. K. Yi and K. Kim, Sci. Rep., 2016, 6, 28443.

72. S. Liu, H. Ming, T. H. Zeng, R. Wu, R. Jiang, J. Wei, L. Wang, J. Kong and Y. Chen, Langmuir, 2012, 28, 12364-12372.

73. O. Akhavan, E. Ghaderi and A. Esfandiar, J. Phys. Chem. B, 2011, 115, 6279-6288.

74. O. Akhavan and E. Ghaderi, Carbon, 2012, 50, 1853-1860.

75. W. Hu, C. Peng, W. Luo, M. Lv, X. Li, D. Li, Q. Huang and C. Fan, ACS Nano, 2010, 4, 4317-4323.

76. N. Kurantowicz, E. Sawosz, S. Jaworski, M. Kutwin, B. Strojny, M. Wierzbicki, J. Szeliga, A. Hotowy, L. Lipinska, R. Kozinski, J. Jagiello and A. Chwalibog, Nanoscale Res. Lett., 2015, 10, 23.

77. K. Krishnamoorthy, M. Veerapandian, L.-H. Zhang, K. Yun and S. J. Kim, J. Phys. Chem. C, 2012, 116, 17280-17287.

78. Y. Xie, B. Wu, X.-X. Zhang, J. Yin, L. Mao and M. Hu, Chemosphere, 2016, 144, 13061312.

79. J. Chen, H. Peng, X. Wang, F. Shao, Z. Yuan and H. Han, Nanoscale, 2014, 6, 18791889.

80. S. Gurunathan, J. W. Han, A. A. Dayem, V. Eppakayala and J.-H. Kim, Int. J. Nanomed., 2012, 7, 5901-5914.

81. M. Veerapandian, L.-H. Zhang, K. Krishnamoorthy and K. Yun, Nanotechnology, 2013, 24, 395706.

82. S. Gurunathan, J. W. Han, A. A. Dayem, V. Eppakayala, M.-R. Park, D.-N. Kwon and J. H. Kim, J. Ind. Eng. Chem., 2013, 49, 1280-1288.

83. B. Z. Ristic, M. M. Milenkovic, I. R. Dakic, B. M. Todorovic-Mrkoviv, M. S. Milosavljevic, M. M. Budimir, V. G. Paunovic, M. D. Dramicanin, Z. M. Markovic and V. S. Trajkovic, Biomaterials, 2014, 34, 4428-4435.

DOI: $10.1039 /$ C6TB01647B - Journal: Journal of Materials Chemistry B: Materials for biology and medicine - Post-print 
84. O. Akhavan and E. Ghaderi, ACS Nano, 2010, 4, 5731-5736.

85. J. Zhao, B. Deng, M. Lv, J. Li, Y. Zhang, H. Jiang, C. Peng, J. Li, J. Shi, Q. Huang and C. Fan, Adv. Healthcare Mater., 2013, 2, 1259-1266.

86. J. D. Mangadlao, C. M. Santos, M. J. L. Felipe, A. C. C. de Leon, D. F. Rodrigues and R. C. Advincula, Chem. Commun., 2015, 51, 2886-2889.

87. J. Li, G. Wang, H. Zhu, M. Zhang, X. Zheng, Z. Di, X. Liu and X. Wang, Sci. Rep., 2014, 4, 4359.

88. S. S. Nanda, S. S. A. An and D. K. Yi, Int. J. Nanomed., 2015, 10, 549-556.

89. L. Hui, J. G. Piao, J. Auletta, K. Hu, Y. Zhu, T. Meyer, H.-Y. Liu and L. Yang, ACS Appl. Mater. Interfaces, 2014, 6, 13183-13190.

90. Y. Tu, M. Lv, P. Xiu, T. Huynh, M. Zhang, M. Castelli, Z. Liu, Q. Huang, C. Fan, H. Fang and R. Zhou, Nat. Nanotechnol., 2013, 8, 594.

91. Y. Li, H. Yuan, A. von dem Buscche, M. creighton, R. H. Hurte, A. B. Kane and H. Gao, Proc. Natl. Acad. Sci. U. S. A., 2013, 110, 12295-12300.

92. X. Yi and H. Gao, Nanoscale, 2015, 7, 5457-5467.

93. M. Dallavalle, M. Calvaresi, A. Bottini, M. Melle-France and F. Zerbetto, ACS Appl. Mater. Interfaces, 2015, 7, 4406-4414.

94. V. T. H. Pham, V. Khanh Truong, M. D. J. Quinn, S. M. Notley, Y. Guo, V. A. Baulin, M. Al Kobaisi, R. J. Crawford and E. P. Ivanova, ACS Nano, 2015, 9, 8458-8467.

95. B. Luan, T. Huynh, 1. Zhao and R. Zhou, ACS Nano, 2015, 9, 663-669.

96. C. Xie, X. Lu, L. Han, J. Xu, Z. Q. Wang, L. Jiang, K. Wang, H. B. Zhang, F. Ren and Y. Tang, ACS Appl. Mater. Interfaces, 2016, 8, 1707-1717.

97. X.-Z. Tang, C. Mu, W. Zhu, X. Yan, X. Hu and J. Yang, Carbon, 2016, 98, 432-440.

98. I. E. Mejías Carpio, C. M. Santos, X. Wei and D. F. Rodrigues, Nanoscale, 2012, 7, 4746-4756.

99. S. Park, N. Mohanty, J. W. Suk, A. Nagaraja, J. An, R. Pinr, W. Cai, D. R. Dryer, V. Berry and R. S. Ruoff, Adv. Mater., 2010, 22, 1736-1740.

100. Q. Tu, C. Tian, T. Ma, L. Pang and J. Wang, Colloid Surf., B, 2016, 141, 196205.

101. N. Mahmoudi, F. Ostadhossein and S. Abdolreza, J. Appl. Polym. Sci., 2016, $133,43194$.

102. H. E. Karahan, L. Wei, K. Goh, C. Wiraja, Z. Liu, C. Xu, R. Jiang, J. Wei and Y. Chen, Small, 2016, 12, 951-962.

103. X. N. Yang, D. D. Xue, J. Y. Li, M. Liu, S. R. Jia, L. Q. Chu, F. Wahid, Y. M. Zhang and C. Zhong, Carbohydr. Polym., 2016, 136, 1152-1160.

104. R. Kurapati, M. Vaidyanathan and A. A. Raichur, RSC Adv., 2016, 6, 3985239860.

105. P. Li, S. Sun, A. Dong, Y. Hao, S. Shia, Z. Sun, G. Gao and Y. Chen, Appl. Surf. Sci., 2015, 355, 446-452.

106. T. Kavitha, I.-K. Kang and S.-Y. Park, Polym. Int., 2015, 64, 1660-1666.

$107 . \quad$ L. He, L. F. Dumée, C. Feng, L. Velleman, R. Reis, F. She, W. Gao and L. Kong, Desalination, 2015, 365, 126-135.

108. H.-P. Liang, Z. Su, Y. Wang and S. Wang, J. Inorg. Mater., 2015, 30, 516.

109. T. Huang, L. Zhang, H. Chen and C. Gao, J. Mater. Chem. B, 2015, 3, 16051611.

$110 . \quad$ C. He, Z.-Q. Shi, L. Ma, C. Cheng, C.-X. Nie, M. Zhoua and C.-S. Zhao, J. Mater. Chem. B, 2015, 3, 592-602.

DOI: 10.1039/C6TB01647B - Journal: Journal of Materials Chemistry B: Materials for biology and medicine - Post-print 
111. P. K. S. Mural, A. Banerjee, M. S. Rana, A. Shukla, B. Padmanabhan, S. Bhadra, G. Madras and S. Bose, J. Mater. Chem. A, 2014, 2, 17635.

112. M. Mazaheri, O. Akhavan and A. Simchi, Appl. Surf. Sci., 2014, 301, 456-462.

113. Y. Liu, M. Park, H. K. Shin, B. Pant, J. Choi, Y. W. Park, J. Y. Lee, S.-J. Park and H.-Y. Kim, J. Ind. Eng. Chem., 2014, 20, 4415-4420.

114. H. M. Hegab, A. ElMekawy, T. G. Barclay, A. Michelmore, L. Zou, C. P. Saint and M. Ginic-Markovic, ACS Appl. Mater. Interfaces, 2015, 7, 18004-18016.

115. C. Bora, P. Bharali, S. Baglari, S. K. Dolui and B. K. Konwar, Compos. Sci. Technol., 2013, 87, 1-7.

116. L. Duan, Y. Wang, Y. Zhang and J. Liu, Appl. Surf. Sci., 2015, 355, 436-445.

$117 . \quad$ Z.-B. Zhang, J. J. Wu, Y. Su, J. Zhou, Y. Gao, H.-Y. Yu and J.-S. Gu, Appl. Surf. Sci., 2015, 332, 300-307.

118. L. Yu, Y. Zhang, B. Zhang, J. Liu, H. B. Zhang and C. Song, J. Membr. Sci., 2013, 447, 452-462.

$119 . \quad$ L. Hui, J. T. Auletta, Z. H. Huang, X. Chen, F. Xia, S. Yang, H. Liu and L. Yang, ACS Appl. Mater. Interfaces, 2015, 7, 10511-10517.

120. X. Wang, Z. Liu, X. Ye, K. Hu, H. Zhong, X. Yuan, H. Xiong and Z. Guo, Chem. Eng. J., 2015, 260, 331-337.

121. Y. Wang, P. Zhang, C. F. Liu and C. Z. Huang, RSC Adv., 2013, 3, 9240.

122. R. Kanchanapally, B. P. Viraka Nellore, S. S. Sinha, F. Pedraza, S. J. Jones, A. Pramanik, S. R. Chavva, C. Tchounwou, Y. Shi, A. Vangara, D. Sardarb and P. C. Ray, RSC Adv., 2015, 5, 18881-18887.

123. J. Ma, J. Zhang, Z. Xiong, Y. Yong and X. S. Zhao, J. Mater. Chem., 2011, 21, 3350-3352.

124. X. Cai, M. Lin, S. Tan, W. Mai, Y. Zhang, Z. Liang, Z. Lin and X. Zhang, Carbon, 2012, 50, 3407-3415.

125. M. R. Das, R. K. Sarma, R. Saikia, V. S. Kale, M. V. Shelke and P. Sengupta, Colloid Surf., B, 2011, 83, 16.

126. V. Vantanpour, A. Shockravi, H. Zarrabi, Z. Nikjavan and A. Javadi, J. Ind. Eng. Chem., 2015, 30, 342-352.

127. E. Mahmoudi, L. Y. Ng, M. M. Ba-Abbad and A. W. Mohallad, Chem. Eng. J., 2015, 277, 1-10.

128. A. F. de Faria, F. Perreault, E. Shaulsky, L. H. Arias Chavez and M. Elimelech, ACS Appl. Mater. Interfaces, 2015, 7, 12751-12759.

129. A. Kumar and C. H. Lee, Synthesis and Biomedical Applications of Graphene: Present and Future Trends; in Nanotechnology and Nanomaterials, in "Advances in

Graphene Science”, ed. M. Aliofkhazraei, INTECH, 2013, ch. 3.

130. Z. Zhu, M. Su, L. Ma, L. Ma, D. Liu and Z. Wang, Talanta, 2013, 117, 449-455.

131. M. R. Das, R. K. Sarma, S. Borah, R. Kumari, R. Saikia, A. B. Deshmukh, M.

V. Shelke, P. Sengupta, S. Szunerits and R. Boukherroub, Colloid Surf., B, 2013, 105, $128-136$.

132. V. H. Nguyen, B. K. Kim, Y.-L. Lo and J. J. Shim, J. Supercrit. Fluids, 2012, $72,28-35$.

133. L. Huang and H. Yang, J. Nanomater., 2016, 5685967.

134. Q. Bao, D. Zhang and P. Qi, J. Colloid Interface Sci., 2011, 360, 463-470.

135. A. C. de Moraes, B. A. Lima, A. F. de Faria, M. Brocchi and O. L. Alves, Int. J. Nanomed., 2015, 10, 6847-6861.

DOI: 10.1039/C6TB01647B - Journal: Journal of Materials Chemistry B: Materials for biology and medicine - Post-print 
136. R. G. Bai, K. Muthoosamy, F. N. Shipton, A. Pandikumar, P. Rameshkumar, N. M. Huang and S. Manickam, RSC Adv., 2016, 6, 36576-36587.

137. Y. Zhou, J. Yang, T. He, H. Shi, X. Cheng and Y. Lu, Small, 2013, 9, 34453454.

138. P. Zhang, H. Wang, X. Zhang, W. Xu, Q. Li, G. Wei and Z. Su, Biomater. Sci., 2015, 3, 852-860.

139. Z. J. Fan, B. Liu, J. Wang, S. Zhang, Q. Lin, P. Gonh, L. Ma and S. Yang, Adv. Funct. Mater., 2014, 24, 3933.

140. H. Yun, M. S. Ahmed, K. Lee, S. Jeon and C. W. Lee, Appl. Surf. Sci., 2016, 360, 915-920.

141. C. Zhao, B. Deng, G. Chen, B. Lei, H. Hua, H. Peng and Z. Yan, Nano Res., 2016, 9, 963-973.

142. J. Cui and Y. Liu, RSC Adv., 2015, 5, 85748-85755.

143. X. Zeng, D. T. McCarthy, A. Deletic and X. Zahng, Adv. Funct. Mater., 2015, 25, 4344-4351.

144. S. Singh, R. K. Gundampati, K. Mitra, K. Ramesh, M. V. Jagannadham, N. Misra and B. Ray, RSC Adv., 2015, 5, 81994-82004.

145. A. Soroush, W. Ma, M. Cry, B. Rahaman, N. Asadishad and N. Tufenkji, Sci. Technol. Lett., 2016, 3, 13-18.

146. B. Marat, M. Potara, M. Iliuta, E. Jakabc, T. Radue, F. Imre-LMucacud, G. Katonah, O. Popescu and S. Astileana, Colloids Surf., 2015, 487, 113-120.

147. X. Chen, X. Huang, C. Zheng, Y. L. Liu, T. Xu and J. Liu, J. Mater. Chem. B, 2015, 3, 7020 .

148. L. Shahriary, R. Nair, S. Sabharwal and A. A. Athawale, New J. Chem., 2015, 39, 4583-4590.

149. P. K. S. Mural, M. Sharma, A. Shukla, S. Bhadra, B. Padmanabhan, G. Madras and S. Suryasarathi Bose, RSC Adv., 2015, 5, 32441.

150. L. Yu, Y. Zhang, B. Zhang and J. Liu, Sci. Rep., 2014, 4, 455.

151. N. Hussain, A. Gogoi, R. K. Sarma, P. Sharma, A. Barras, R. Boukherroub, R. Saikia, P. Sengupta and M. R. Das, ChemPlusChem, 2014, 79, 1774-1784.

152. K. Turcheniuk, C.-H. Hage, J. Spadavecchia, A. Y. Serrano, I. Larroulet, A. Pesquera, A. Zurutuza, M. G. Pisfil, L. Heliot, J. Bouckaert, R. Boukherroub and S. Szunerits, J. Mater. Chem. B, 2015, 3, 375-386.

153. I. Saikia, S. Sonowal, M. Pal, P. K. Boruah, M. R. Das and C. Tamuly, Mater. Lett., 2016, 178, 239-242.

154. Y. Ouyang, X. Cai, Q. Shi, L. Liu, D. Wan, S. Tan and Y. Ouyang, Colloids Surf., B, 2013, 107, 107-114.

155. O. Akhavan and E. Ghaderi, J. Phys. Chem. C, 2009, 113, 20214-20220.

156. L. Karimi, M. E. Yazdanshena, R. Khajavi, A. Rashidi and M. Mirjalili, Cellulose, 2014, 21, 3813-3827.

157. Y. Kim, S. Park, H. Kim, S. Park, R. S. Ruoff and S.-J. Hwang, Adv. Funct. Mater., 2013, 24, 2288-2294.

158. L. Liu, H. Bai, J. Liu and D. D. Sun, J. Hazard. Mater., 2013, 261, 214.

159. Y.-N. Chang, X.-M. Ou, G.-M. Zeng, J.-L. Gong, C.-H. Deng, Y. Jiang, J. Liang, G.-Q. Yuan, H.-Y. Liu and X. He, Appl. Surf. Sci., 2015, 343, 1-10.

160. W. He, H. Huang, J. Yan and J. Zhu, J. Appl. Phys., 2013, 114, 204701.

161. Y.-W. Wang, A. CAo, Y. Jiang, X. Zhang, J.-H. Liu and Y. Liu, ACS Appl. Mater. Interfaces, 2014, 6, 2791-2798.

DOI: $10.1039 /$ C6TB01647B - Journal: Journal of Materials Chemistry B: Materials for biology and medicine - Post-print 
162. L. Zhong and K. Yun, Int. J. Nanomed., 2015, 10, 79-92.

163. T. Kavitha, A. I. Gopalan, K.-P. Lee and S.-Y. Park, Carbon, 2012, 50, 29943000.

164. A. Nourmohammadi, R. Rahighi, O. Akhavan and A. Moshfegh, J. Alloys Compd., 2014, 612, 380-385.

165. K. Ravichandran, N. Chidhambram and S. Gobalakrishan, J. Phys. Chem. Solids, 2016, 93, 82-90.

$166 . \quad$ A. R. Chowdhuri, S. Tripathy, S. Chandra, S. Roy and S. K. Sahu, RSC Adv., 2015, 5, 49420.

$167 . \quad$ C.-H. Deng, J.-L. Gong, G.-M. Zeng, C. G. Niu, Q. Y. Niu, W. Zhang and H. Y. Liu, J. Hazard. Mater., 2014, 276, 66.

$168 . \quad$ C. Santosh, P. L. Kollu, S. Doshi, M. Sharma, D. Bahadur, M. T. Vanchinathan, P. Saravana, B.-S. Kim and A. N. Grace, RSC Adv., 2014, 4, 28300-28308.

169. S. Zhan, D. Zhu, S. Ma, W. Yu, Y. Jia, Y. Li, H. Yu and Z. Shen, ACS Appl. Mater. Interfaces, 2015, 7, 4290-4298.

170. S. Chella, P. Kollu, E. V. P. R. Komarala, S. Doshi, M. Saranya, S. Felix, R. Ramachandra, P. Saravana, V. L. Koneru, V. Venugopal, S. K. Jeong and A. Nirmala Garca, Appl. Surf. Sci., 2015, 327, 27-36.

171. M.-C. Wu, A. R. Deokar, J.-H. Liao, P.-Y. Shih and Y.-C. Ling, ACS Nano, 2013, 7, 1281-1290.

172. R. Moosavi, S. Ramanathan, Y. Y. Lee, K. C. S. Ling, A. Afkhami, G. Archunan, P. Padmanabhan, B. Gulyas, M. Kakran and S. T. Selvan, RSC Adv., 2015, 5, 7644276450 .

173. N. Wang, B. Hu, M.-L. Che and J.-H. Wang, Nanotechnology, 2015, 26, 195703.

174. S. Ma, S. Zhan, Y. Jia and Q. Zhou, ACS Appl. Mater. Interfaces, 2015, 7, 10576-10586.

175. S. Yu, J. Liu, W. Zhu, Z.-T. Hu, T.-T. Lim and X. Yan, Sci. Rep., 2015, 5, 16369.

176. N. Gao, Y. Chen and J. Jiang, ACS Appl. Mater. Interfaces, 2013, 5, $11307-$ 11314.

177. M. R. Das, Colloids Surf., B, 2011, 16-22.

178. X. Li, Z. Zhang, C. Wang, T. Zhang, K. He and F. Deng, J. Inorg. Biochem., 2011, 105, 23-32.

179. J. Tang, Q. Chen, L. Q. Xu, S. Zhang, L. Feng, L. Cheng, H. Xu, Z. Liu and R. Peng, ACS Appl. Mater. Interfaces, 2013, 5, 3867-3874.

180. S. Chook, C. Chia, S. Zakaria, M. Ayob, K. Chee, N. Huang, H. Neoh, H. Lim, R. Jamal and R. Rahman, Nanoscale Res. Lett., 2012, 7, 1-7.

181. R. Pasricha, S. Gupta and A. K. Srivastava, Small, 2009, 5, 2253-2259.

182. X. Z. Tang, Z. Cao, H. B. Zhang, J. Liu and Z. Z. Yu, Chem. Commun., 2011, 47, 3084-3086.

183. W. Shao, X. Liu, H. Min, G. GDong, Q. Feng and S. Zuo, ACS Appl. Mater. Interfaces, 2015, 7, 6966-6973.

184. S. W. Chook, C. H. Chia, S. Zakaria, M. K. Ayob, N. M. Huang, H. M. Neoh and R. Jarmal, RSC Adv., 2015, 5, 26263-26268.

185. P. Zhang, H. Wang, X. Zhang, W. Xu, Y. Li, Q. Li, G. Wei and Z. Su, Biomater. Sci., 2015, 3, 852-860.

186. Z. M. Xiu, Q. B. Zhang, H. L. Puppala, V. L. Colvin and P. J. Alvarez, Nano Lett., 2012, 12, 4271-4275.

187. L. Liu, J. Liu, Y. Wang and X. Yan, New J. Chem., 2011, 35, 1418-1423.

DOI: 10.1039/C6TB01647B - Journal: Journal of Materials Chemistry B: Materials for biology and medicine - Post-print 
188. D. Lin, T. Qin, Y. Wang, X. Sun and L. Chen, ACS Appl. Mater. Interfaces, $2014,6,1220-1329$.

189. K. Turcheniuk, R. Boukherroub and S. Szunerits, J. Mater. Chem. B, 2015, 3, 4301-4324.

190. A. Markowska-Szczupak, K. Ulfig and A. W. Morawski, Catal. Today, 2011, 169, 249-257.

191. L. Hiu, J. Huang, G. Chen, Y. Zhu and L. Yang, ACS Appl. Mater. Interfaces, 2016, 8, 20-25.

192. H. Sun, N. Gao, K. Dong, J. Ren and X. Qu, ACS Nano, 2014, 8, 6202-6210.

193. C. Wu, C. Wang, T. Han, X. Zhou, S. Guo and J. Zhang, Adv. Healthcare Mater., 2013, 2, 1613-1619

DOI: $10.1039 /$ C6TB01647B - Journal: Journal of Materials Chemistry B: Materials for biology and medicine - Post-print 